\title{
Targeting Intracellular Protein-Protein Interactions with Macrocyclic Peptides
}

\author{
Dehua Pei, PhD \\ Department of Chemistry and Biochemistry \\ ThE OHIO STATE UNIVERSITY
}




\section{Abstract}

We are exploring macrocyclic peptides (including mono- and bicyclic peptides) as a general modality for targeting intracellular protein-protein interactions (PPIs), by leveraging a novel class of highly active cyclic cell-penetrating peptides (CPPs). In the first approach, potent PPI inhibitors such as linear peptides, stapled peptides, cyclic peptides, and proteins, which are generally impermeable to the cell membrane, are rendered cell-permeable and biologically active by conjugating them to a cyclic CPP. In an alternative approach, macrocyclic peptide libraries containing cyclic CPPs are synthesized in the one bead-two compound format and screened for binding to PPI targets of interest, resulting in cell-permeable and biologically active hits directly from library screening. Potent, selective, proteolytically stable, and cell-permeable macrocyclic peptidyl inhibitors have been generated against a variety of intracellular PPIs including the calcineurin-NFAT, $\beta$-catenin-TCF, Keap1-Nrf2, and NEMO-IKK interactions. 


\section{Current Drugs Are Effective for only 20\% Protein Targets}

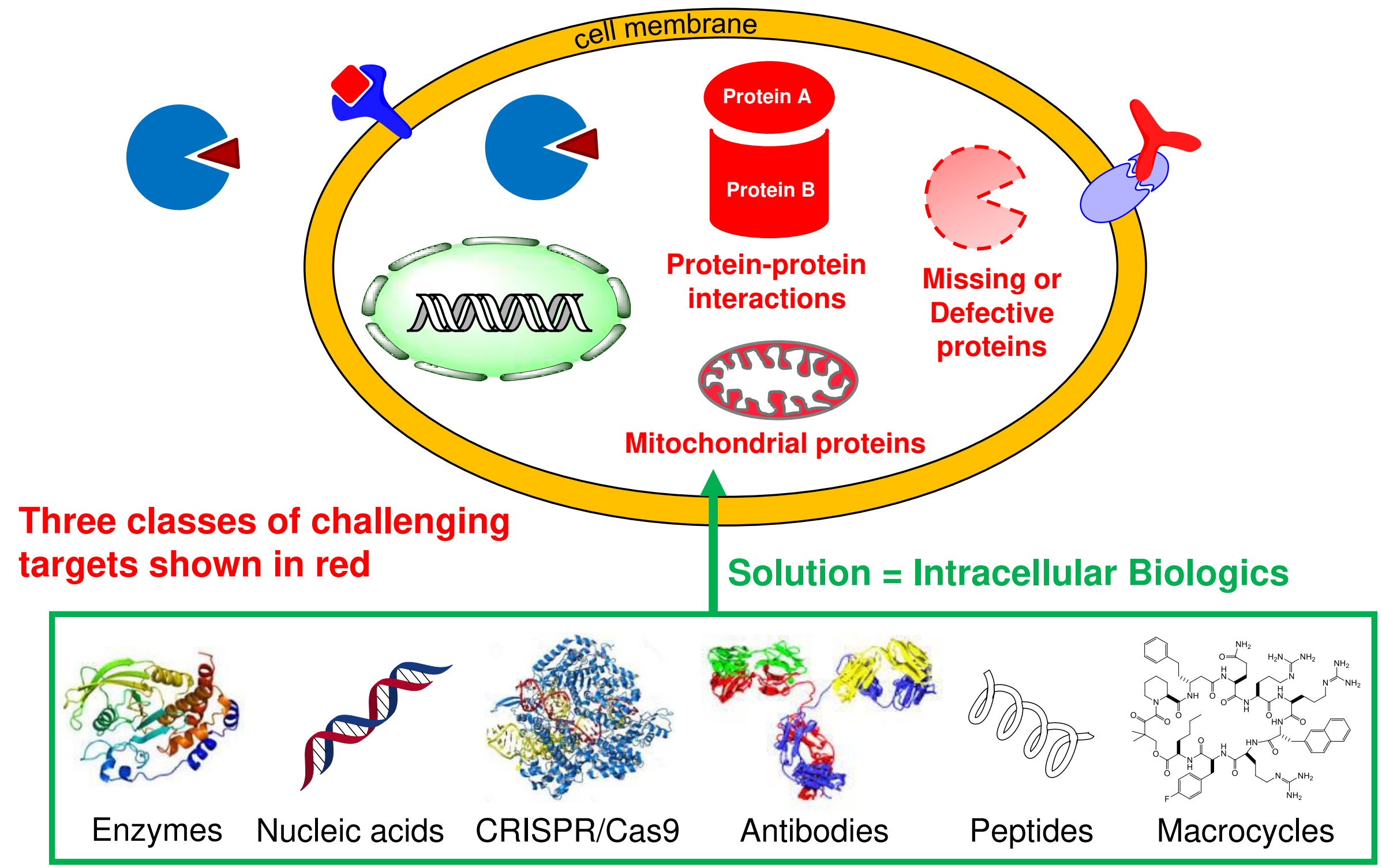




\section{An Intracellular Biologic Requires Two Components:}

- A drug molecule (e.g., a peptide, protein, antibody, or nucleic acid) that effectively modulates (or replaces) the activity of a disease protein; and

- A delivery vehicle that effectively delivers the drug molecule into the cell interior. 


\section{Cyclic Cell-Penetrating Peptides as Highly Active Intracellular Delivery Vehicles}

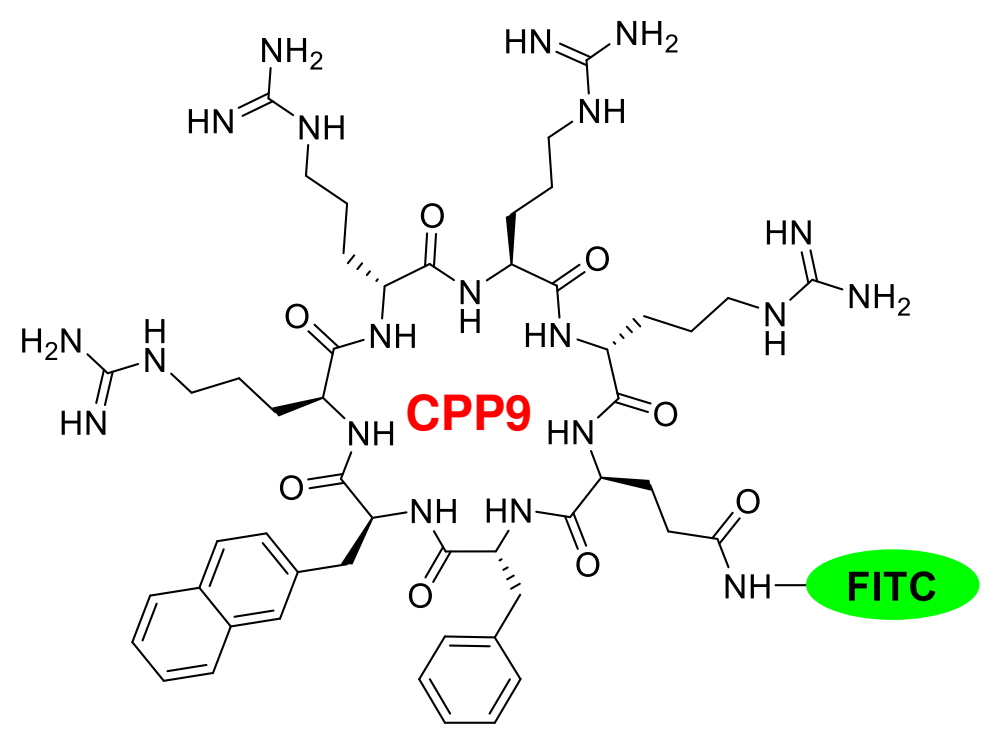

HeLa cells treated with $3 \mu \mathrm{M}$ CPPgFITC:
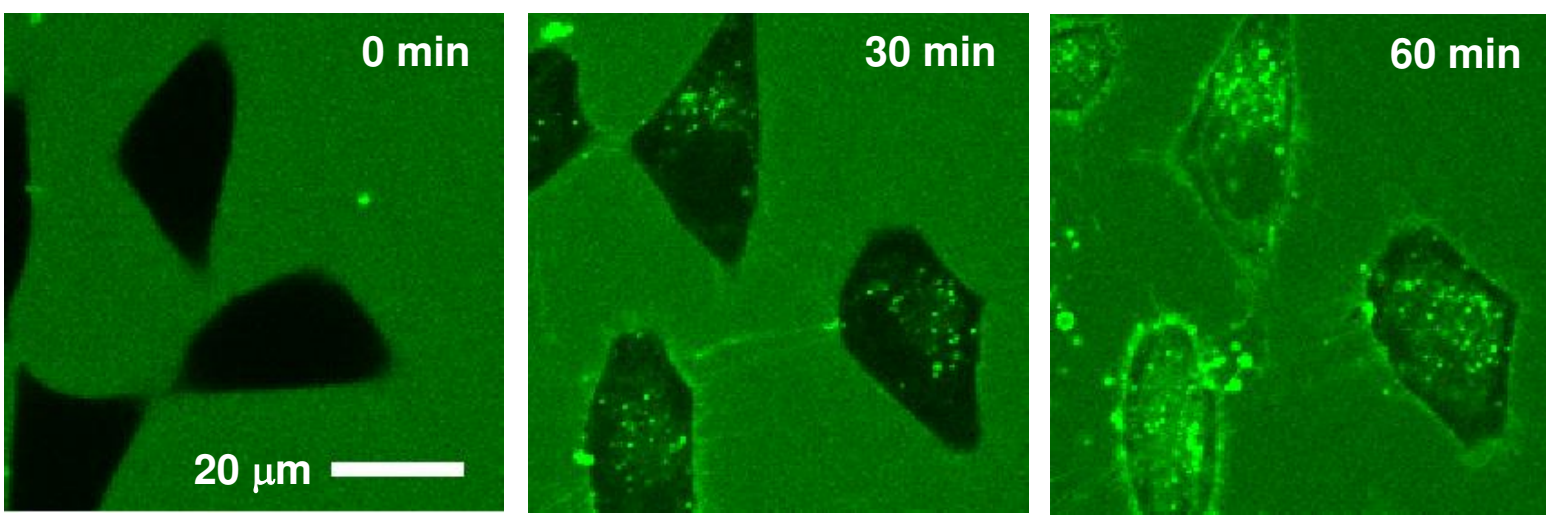

- $>100$ cyclic CPPs discovered

- Up to $120 \%$ cytosolic delivery efficiency

ACS Chem Biol 2013, 8, 423; Biochemistry 2014, 53, 4034; Biochemistry 2016, 55, 2601. 
CPPs Enter Cells by Endocytosis and Exit the Endosome by Inducing Vesicle Budding and Collapse

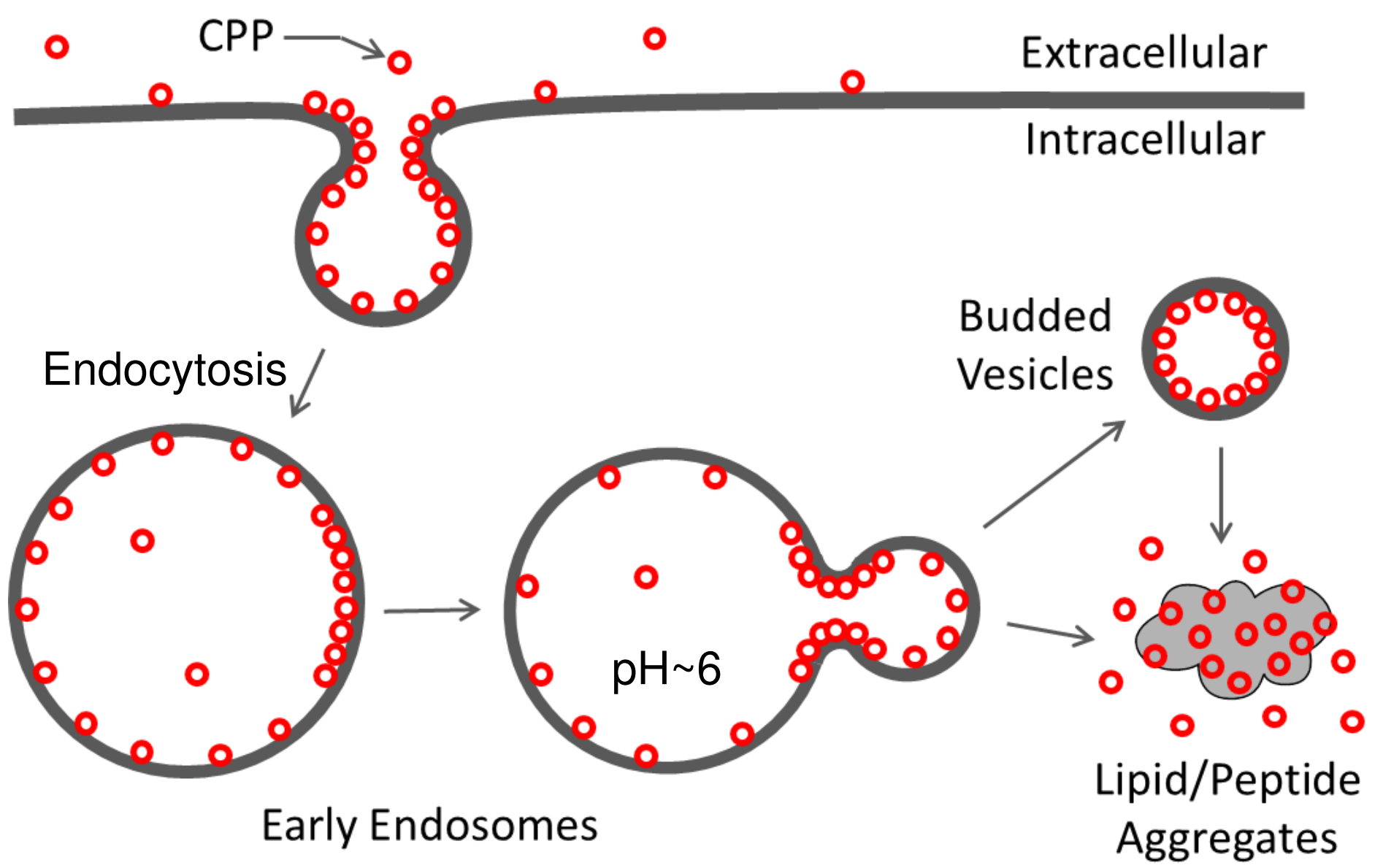

Initially Proposed: Biochemistry 2016, 55, 2601. Reviewed: Bioconj. Chem. 2019, 30, 273. 


\section{Examples of Macrocyclic Peptidyl Inhibitors against Intracellular PPI Targets}

\begin{tabular}{|l|l|l|l|}
\hline Target & Active Modality & Application & Current Status \\
\hline Calcineurin-NFAT & Linear peptide & $\begin{array}{l}\text { Inflammatory diseases, } \\
\text { Organ transplantation }\end{array}$ & In vivo POC \\
\hline B-Catenin-TCF & Stapled peptide & Cancer & In vitro POC \\
\hline Keap1-Nrf2 & Cyclic peptide & Inflammatory diseases & In vitro POC \\
\hline NEMO-IKK & Bicyclic peptide & $\begin{array}{l}\text { Inflammatory diseases, } \\
\text { Cancer }\end{array}$ & $\begin{array}{l}\text { In vitro POC; lead } \\
\text { optimization }\end{array}$ \\
\hline
\end{tabular}




\section{Cytosolic Delivery of Linear Peptides: Inhibitor of Calcineurin-NFAT Interaction}

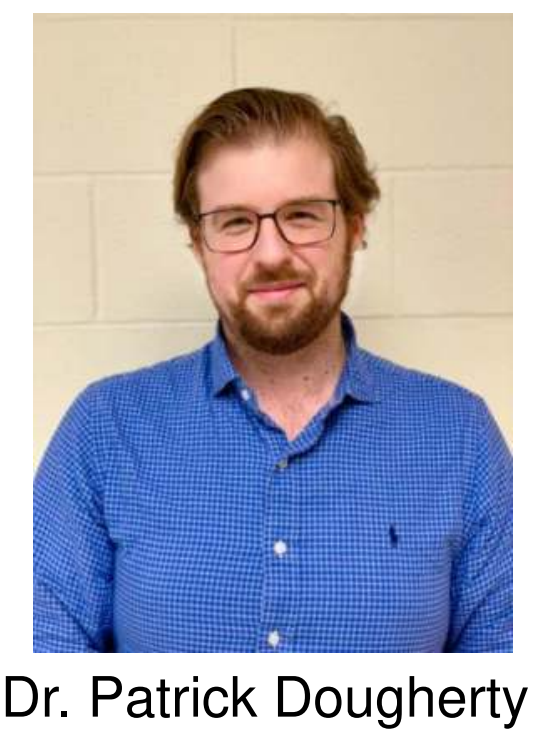

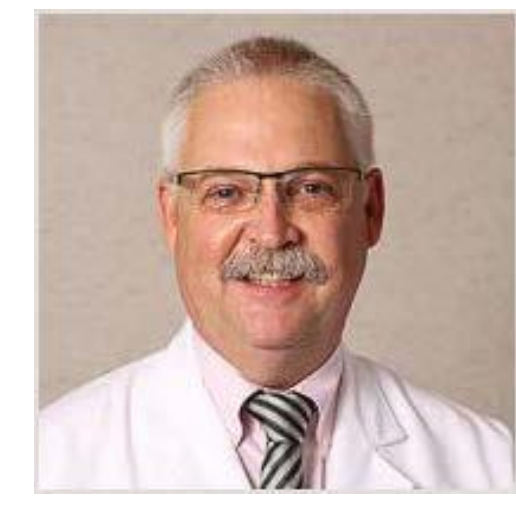

Prof. John Christman

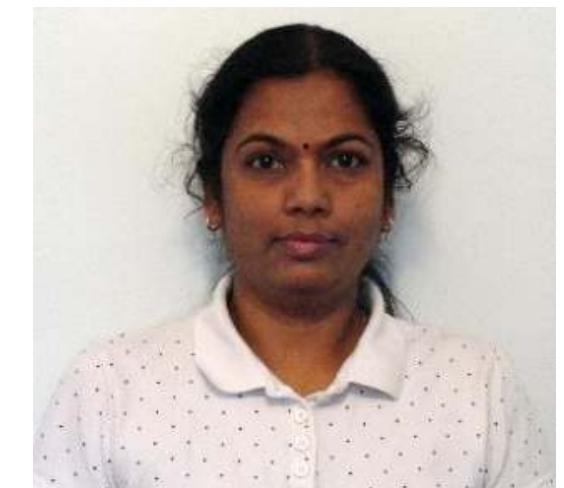

Dr. Manjula Karpurapu

Manuscript in preparation 


\section{Calcineurin, NFAT, and Immunosuppressants}

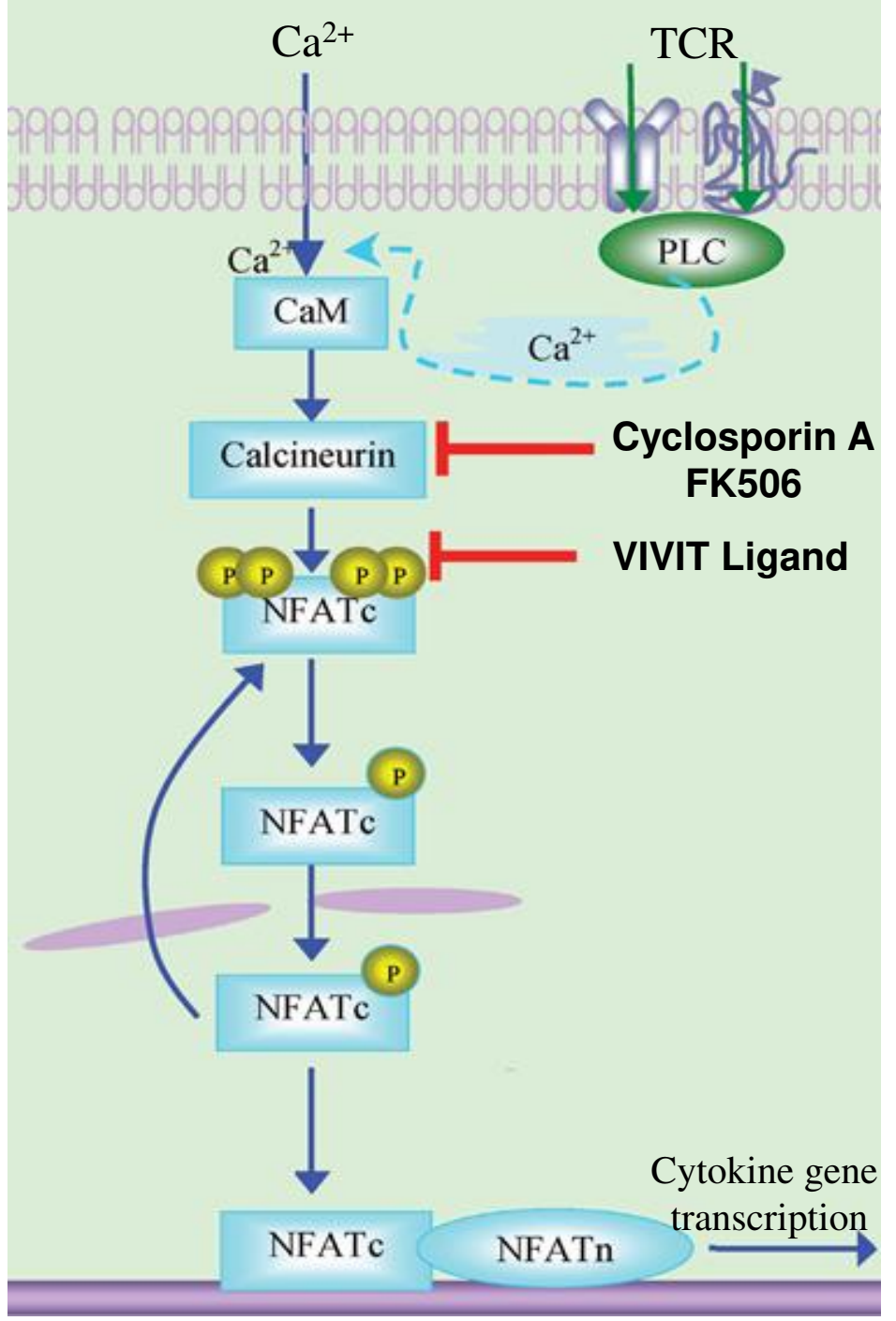

- Current treatment after organ transplantation:

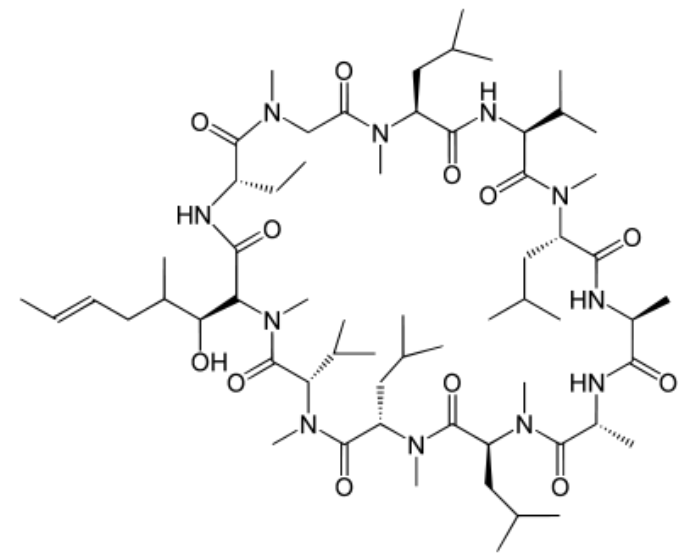

Cyclosporine A (CsA)

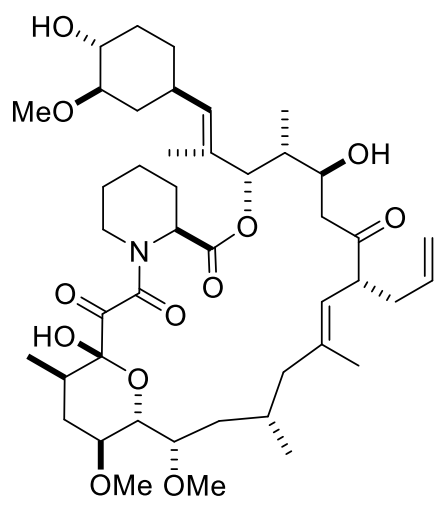

FK506

- Cyclophilin-CsA and FKBP-FK506 complexes bind to calcineurin and sterically block the access of substrates (including NFATs).

- Serious side effects likely due to:

1) inhibition of all CN substrates

2) inhibition of immunophilins

3) off-target effects

J. Liu et al. \& S.L. Schreiber, Cell 1991, 66, 807-815. 


\section{Calcineurin-NFAT Inhibitor as Safer Immunosuppressant}

- The ideal immunosuppressant should:

1) not bind or inhibit immunophilins

2) inhibit CN activity for NFATs only

- $\mathrm{CN}$ recognizes NFATs (and a subset of other substrates) by using a substrate-docking site

- Peptide GPHPVIVITGPHEE (VIVIT) binds to the NFAT-docking site and inhibits $\mathrm{CN}$ activity towards NFATs (L. Cantley, P. Hogan, \& A. Rao, Science 1999)

- $\mathbf{R}_{11}$-VIVIT is effective in mouse models:

1) Organ transplantation (Noguchi et al. Nat. Med. 2004)

2) Inflammatory bowel diseases (Elloumi et al., PLOS ONE 2012)

- Problems:

Low potency $\left(K_{\mathrm{D}}=500 \mathrm{nM}\right)$

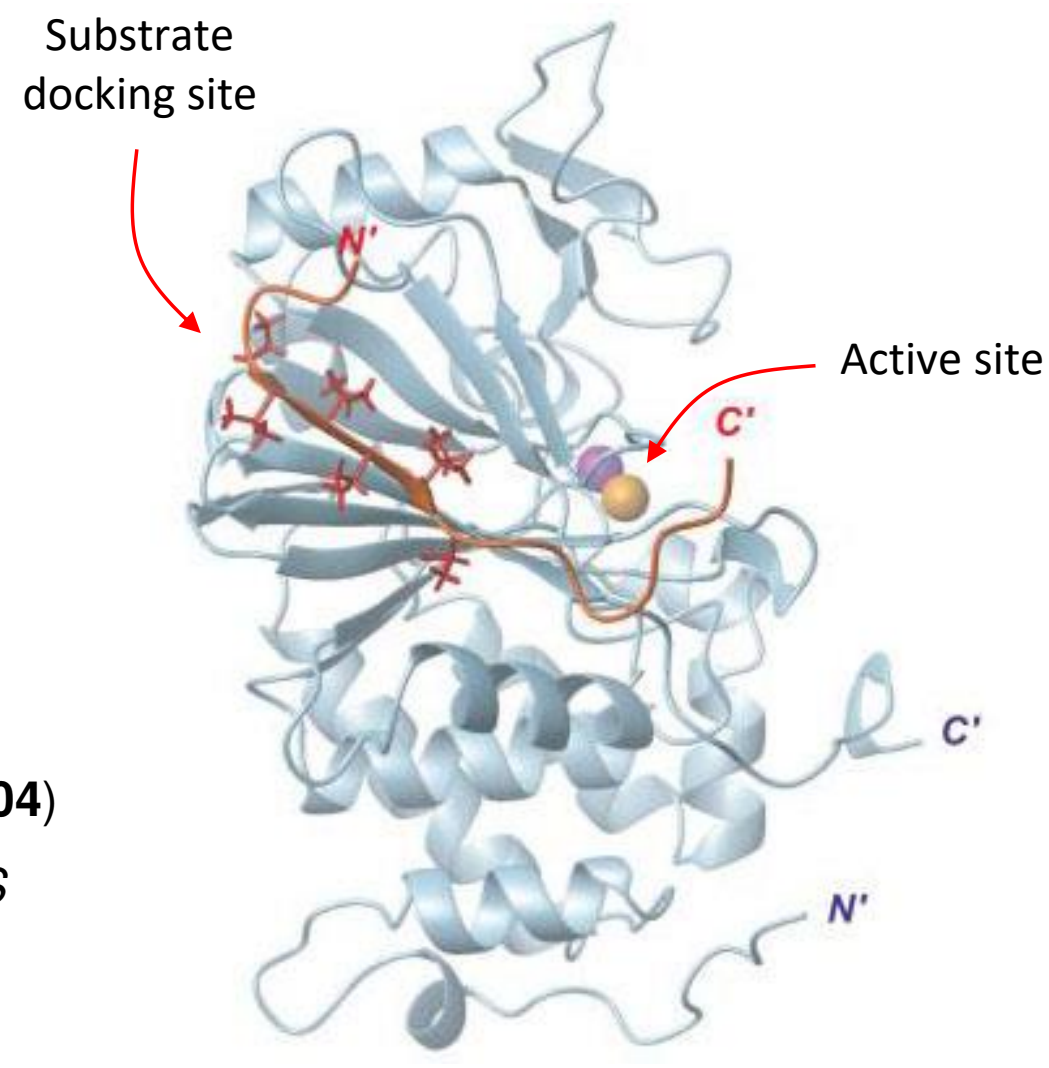

Low cell-permeability

Poor metabolic stability

G. Wagner, Structure 2007 


\section{Optimization of Calcineurin Inhibitor}

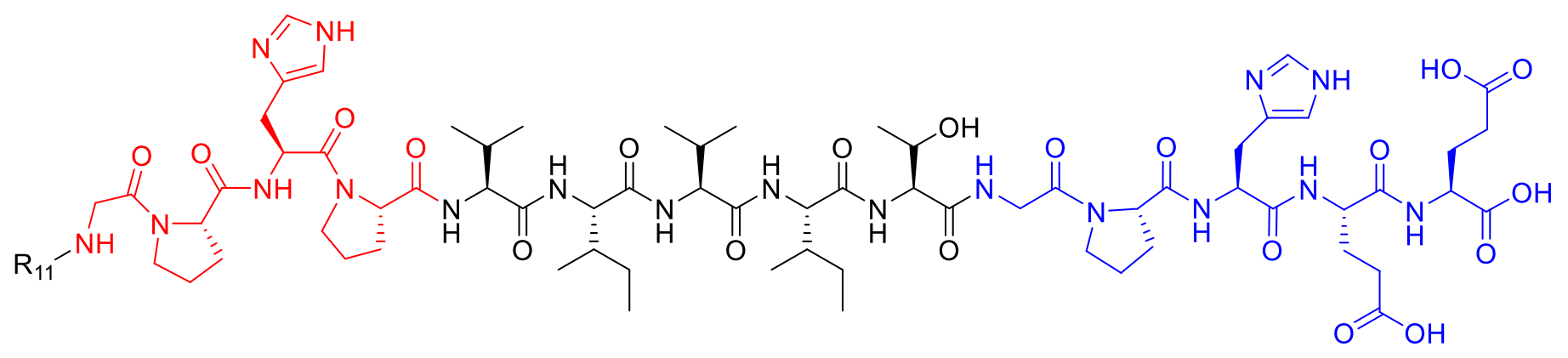

$\mathbf{R}_{11}$-VIVIT $\left(K_{\mathrm{D}} \sim 500 \mathrm{nM}\right.$; serum $\left.t_{1 / 2} \sim 1 \mathrm{~h}\right)$

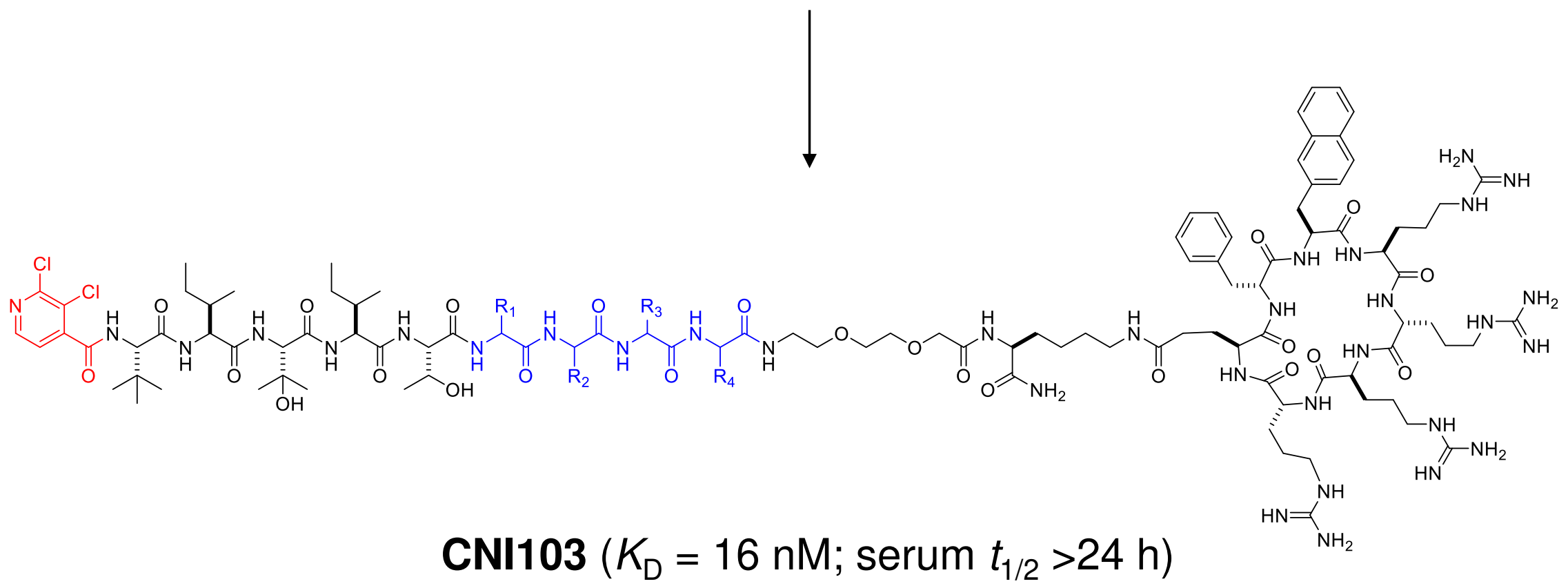

Manuscript in preparation 


\section{Calcineurin Inhibitor CNI103}
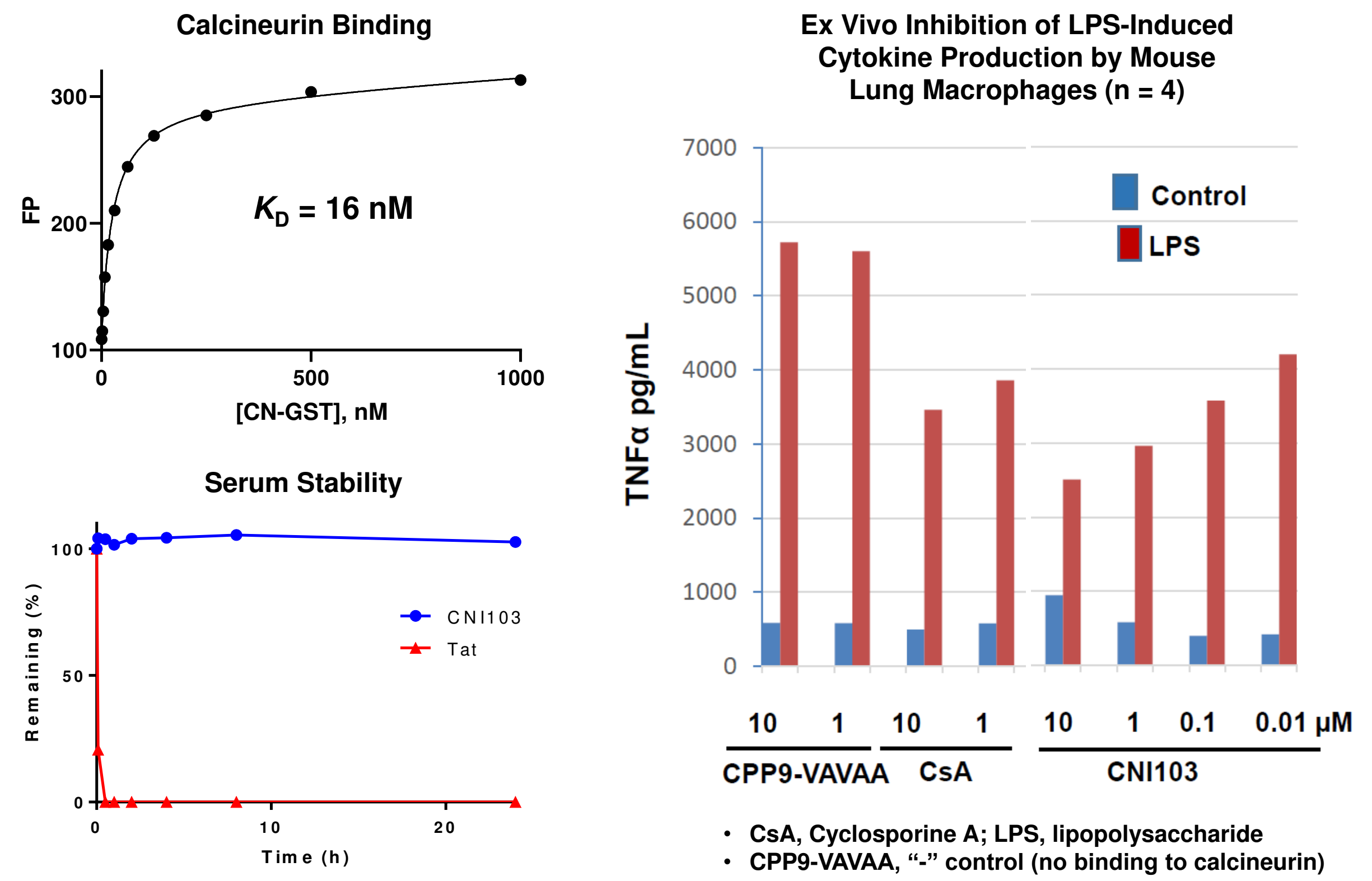


\section{In Vivo Efficacy in Mouse Model of Acute Lung Injury}

- CNI103 administered for $2 \mathrm{~h}$ by nasal insufflation;

- Challenge animals with $2 \mathrm{mg} / \mathrm{kg}$ LPS (intranasal);

- Quantitate cytokines in bronchoalveolar lavage fluid (BALF) after $\geq 2 \mathrm{~h}$.

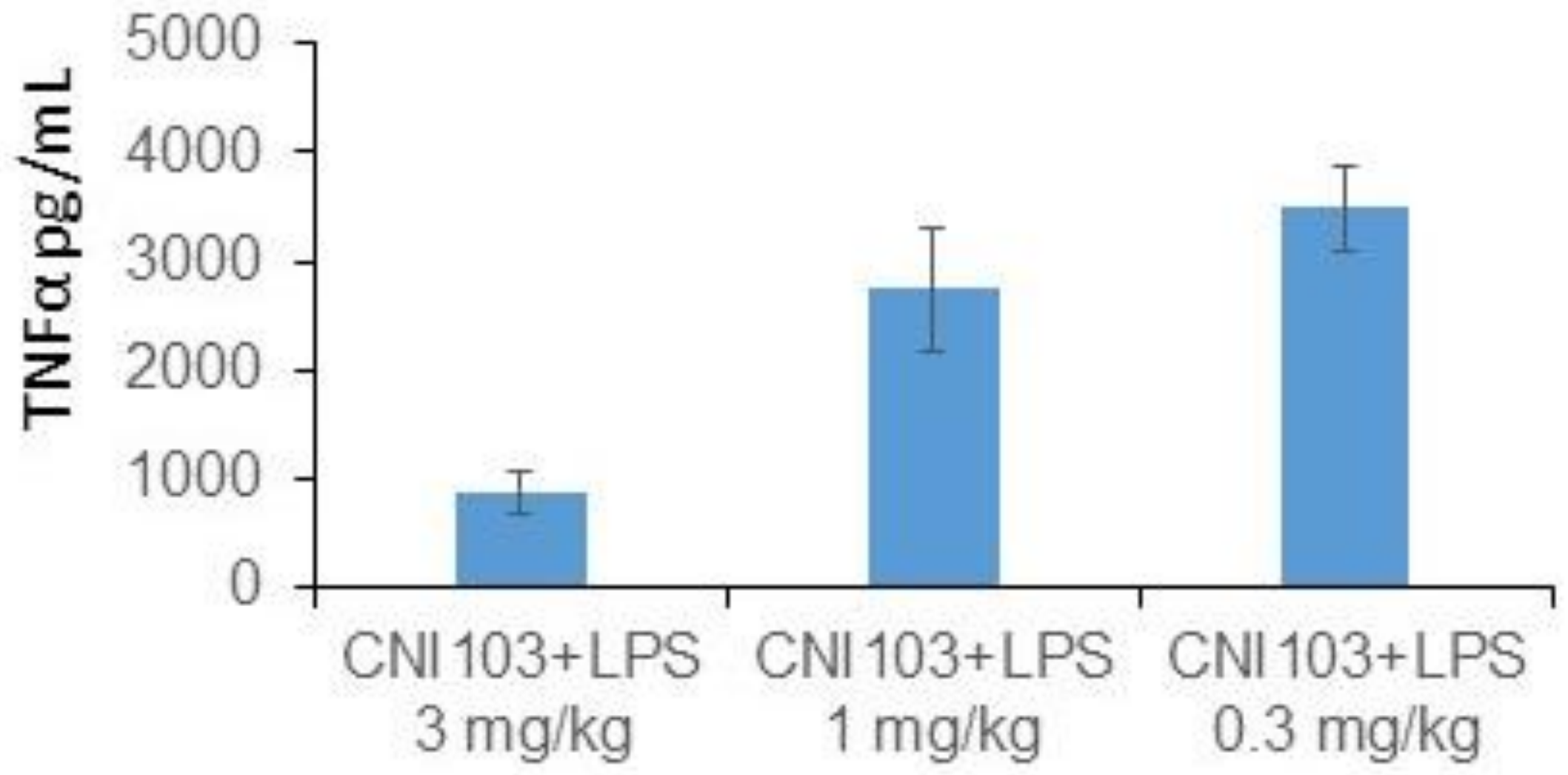

- Result: CNI103 dose-dependently reduces TNF $\alpha$ levels in BALF 


\section{In Vivo Efficacy in Mouse ALI Model - Intranasal}

$3 \mathrm{mg} / \mathrm{kg}$ CNI103 or CPP9-ZIZIT for $2 \mathrm{~h}$ (intranasal) and then $2 \mathrm{mg} / \mathrm{kg}$ LPS (intranasal)
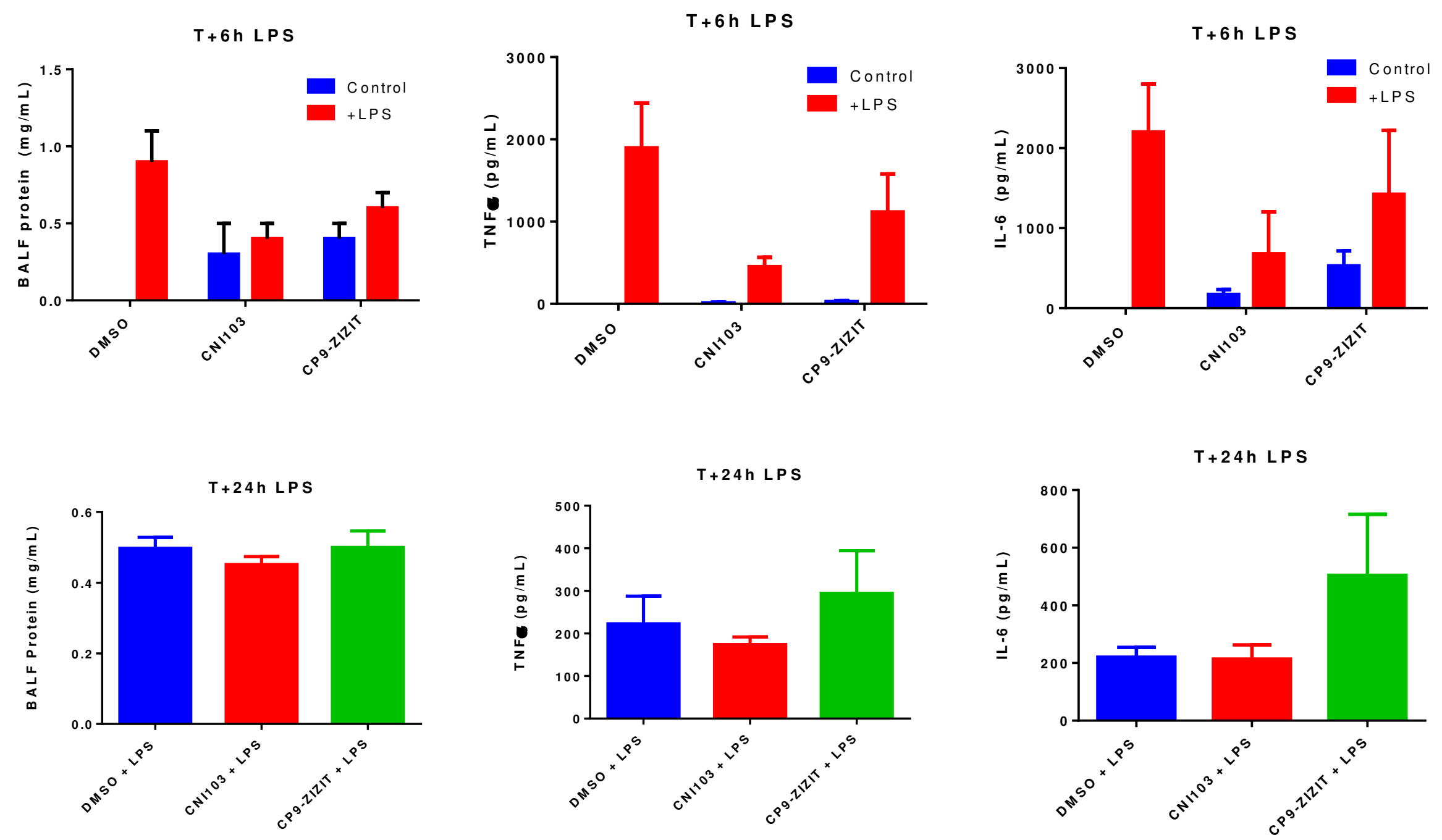

CPP9-ZIZIT is an intermediate with a potency between those of $R_{11}$-VIVIT and CNI103 


\section{In Vivo Efficacy in Mouse ALI Model - Intravenous}

- Mice were dosed with $5 \mathrm{mg} / \mathrm{kg}$ CNI103 (i.v.) for $4 \mathrm{~h}$ and then $2 \mathrm{mg} / \mathrm{kg}$ LPS (intranasal)

- Protein and cytokine levels in BALF and serum were analyzed after $16 \mathrm{~h}$.

\section{Conclusion:}

* CNI103 (intranasal or intravenous) reduces inflammatory cytokine production and prevents permeability pulmonary edema;

- CNI103 penetrates alveolar leukocytes and has excellent PK;

* CNI103 is well tolerated without major toxicities.
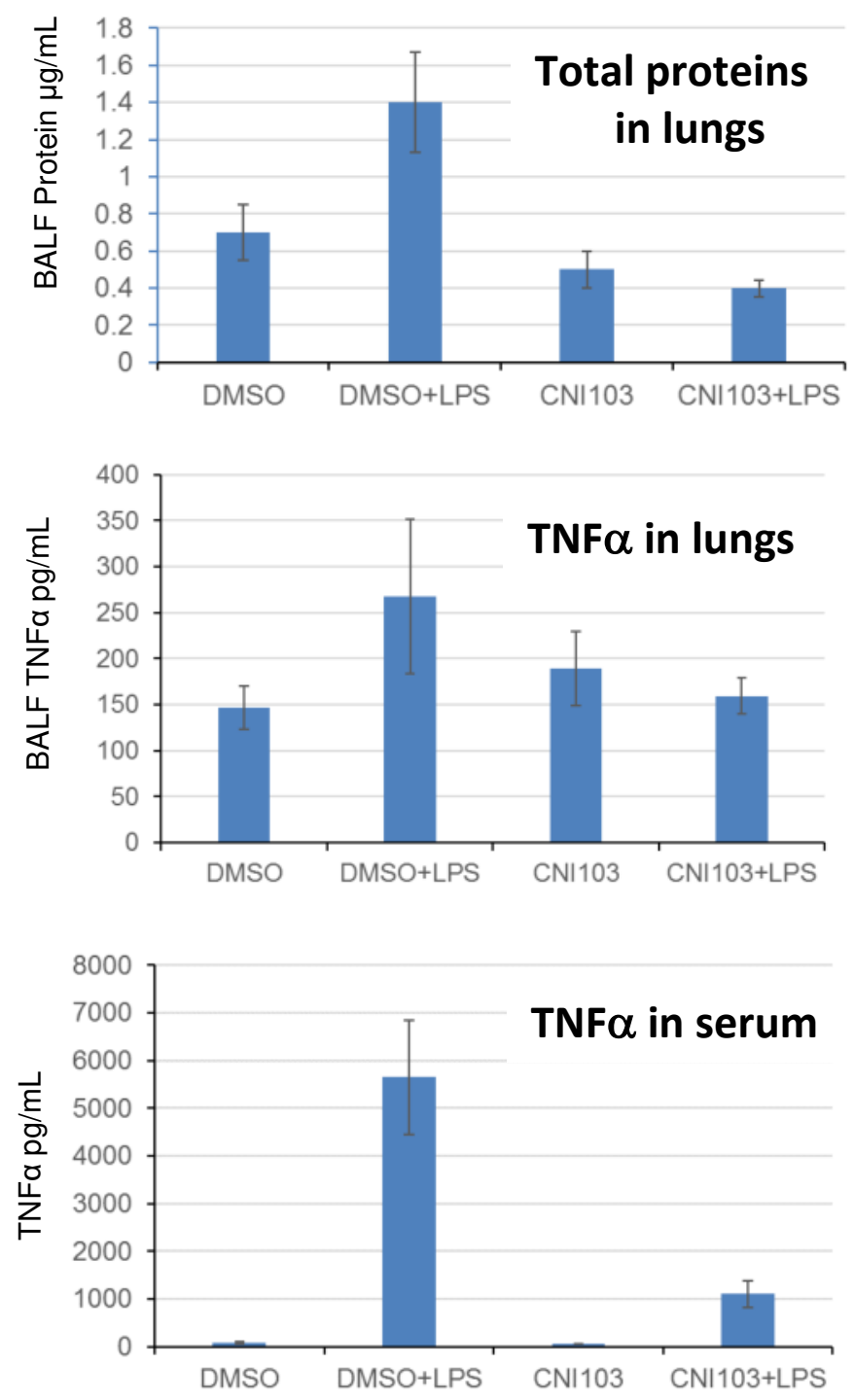


\section{Cytosolic Delivery of Stapled Peptides: $\beta$-Catenin-TCF Interaction Inhibitor}
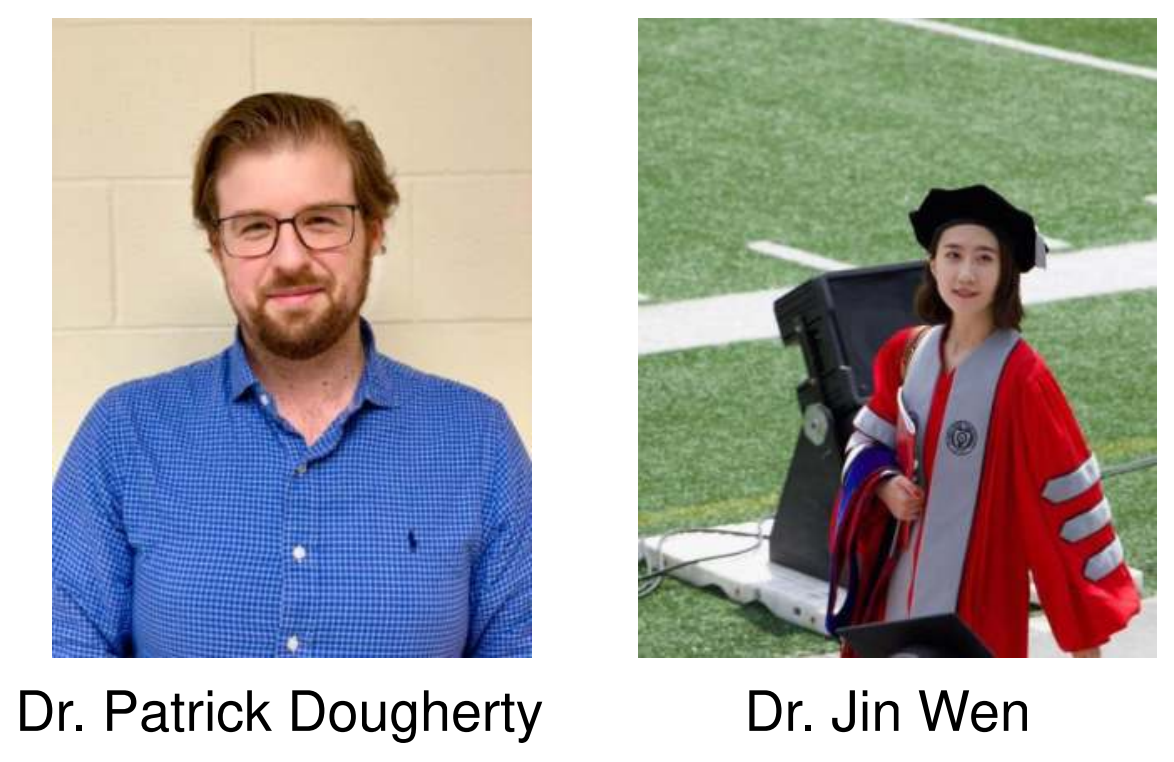

J. Med. Chem. 2019, 62, 10098. 


\section{Stapled Peptides}

Pioneered by: Greg Verdine Loren Walensky

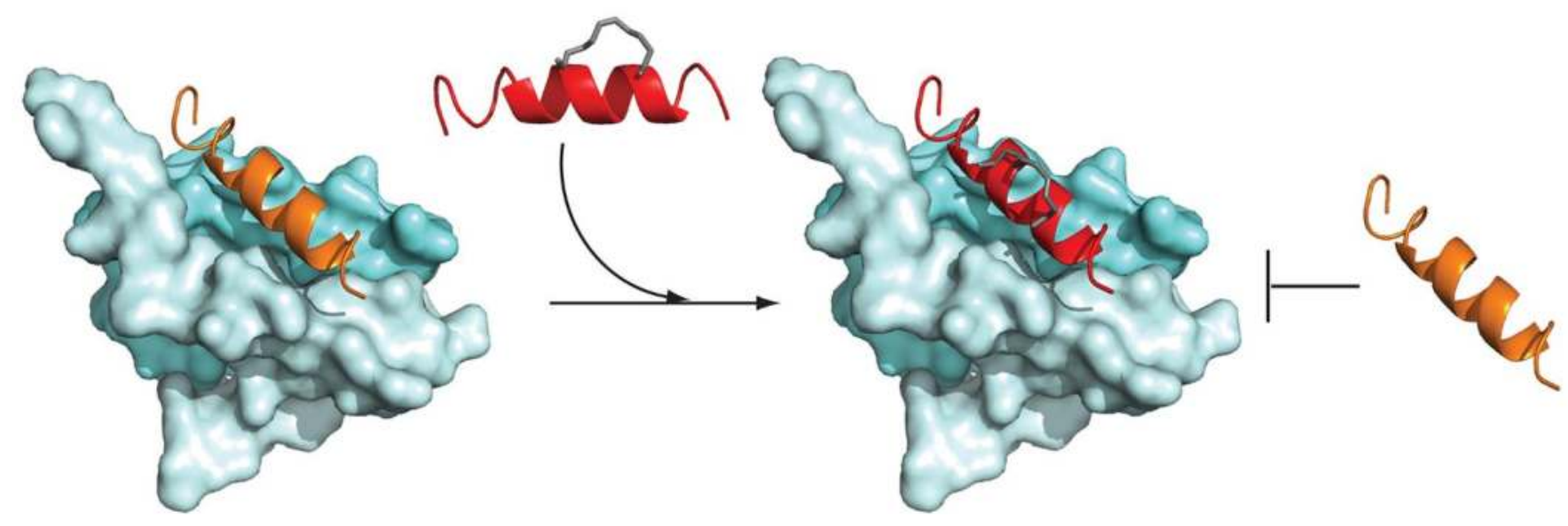

- Enhanced binding affinity and proteolytic stability

- Some stapled peptides are cell-permeable

- Stapled peptide against MDM2-p53 interaction currently in phase II clinical trials (Aileron)

- Major limitation: 1) Most are not cell-permeable; 2) Unpredictable cell-permeability

Can cyclic CPPs confer cell-permeability to stapled peptides?
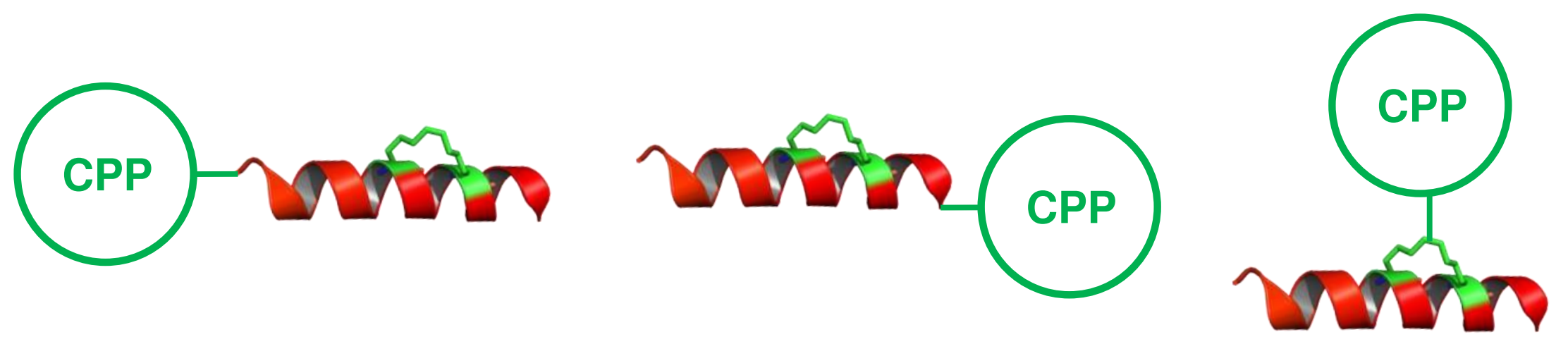


\section{$\beta$-Catenin-TCF Interaction Inhibitors}

Ax4-1-CPP9 (Peptide 9)

$\left(\mathrm{IC}_{50}=152 \pm 8 \mathrm{nM}\right)$

C. Heinis, ACS Chem Biol 2016
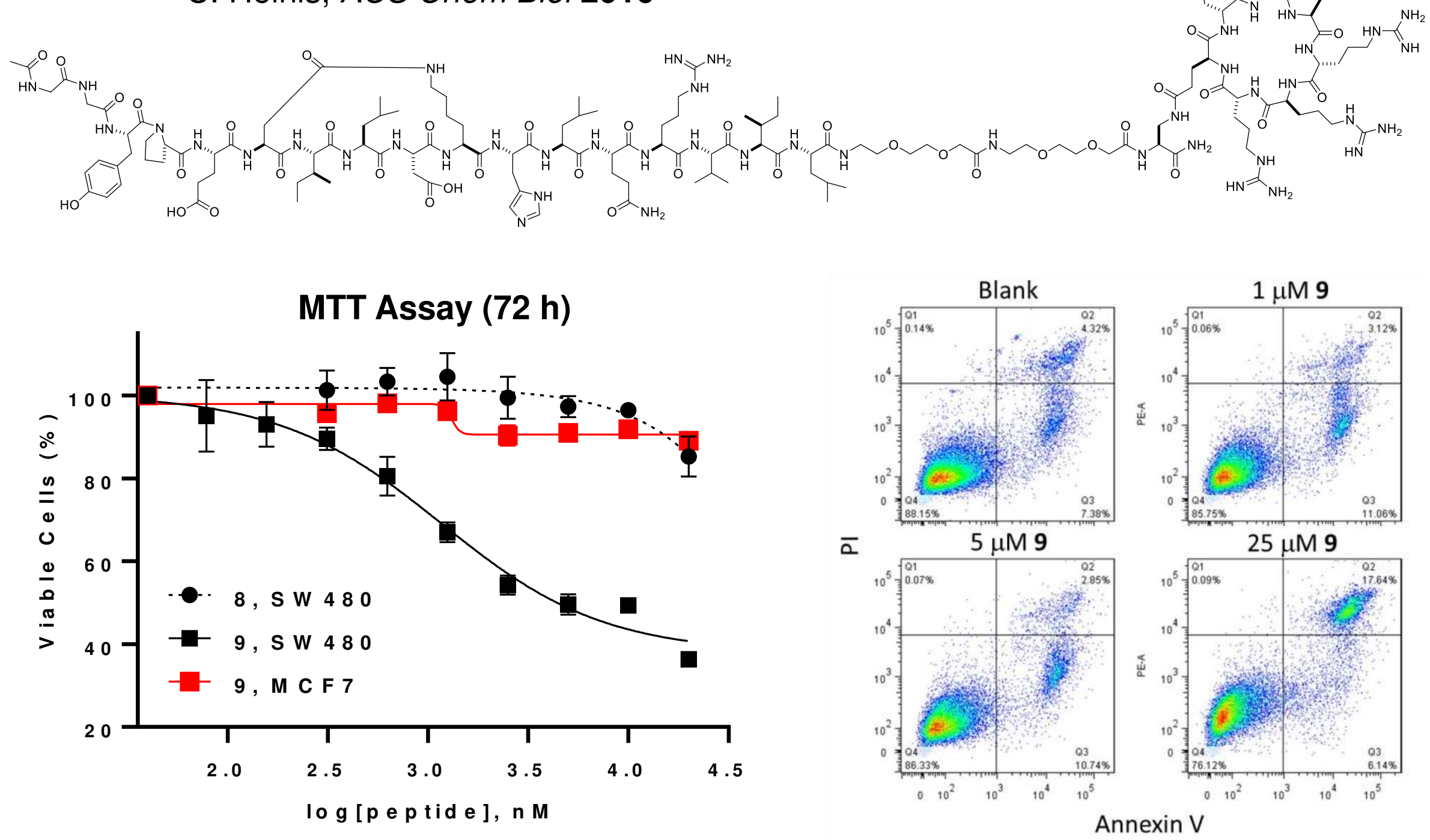


\section{$\beta$-Catenin-TCF Interaction Inhibitors}

Ax4-1-CPP9 (Peptide 9)

$\left(\mathrm{IC}_{50}=152 \pm 8 \mathrm{nM}\right)$

C. Heinis, ACS Chem Biol 2016

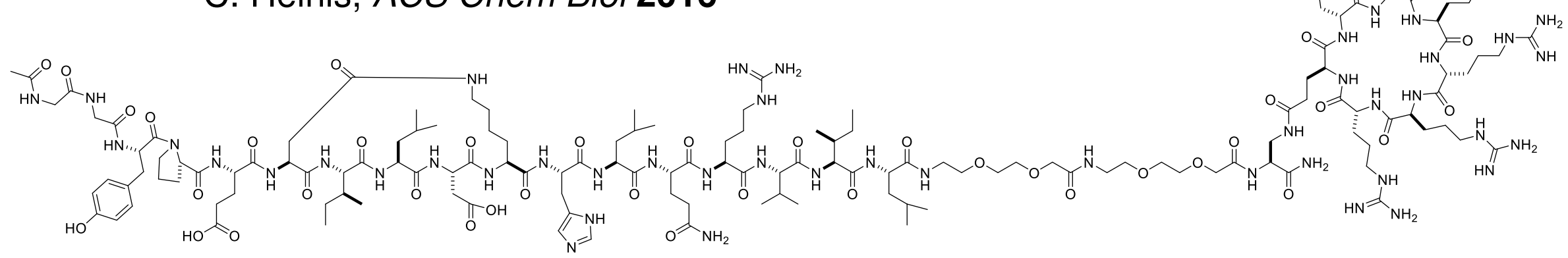

Effect on Target Genes

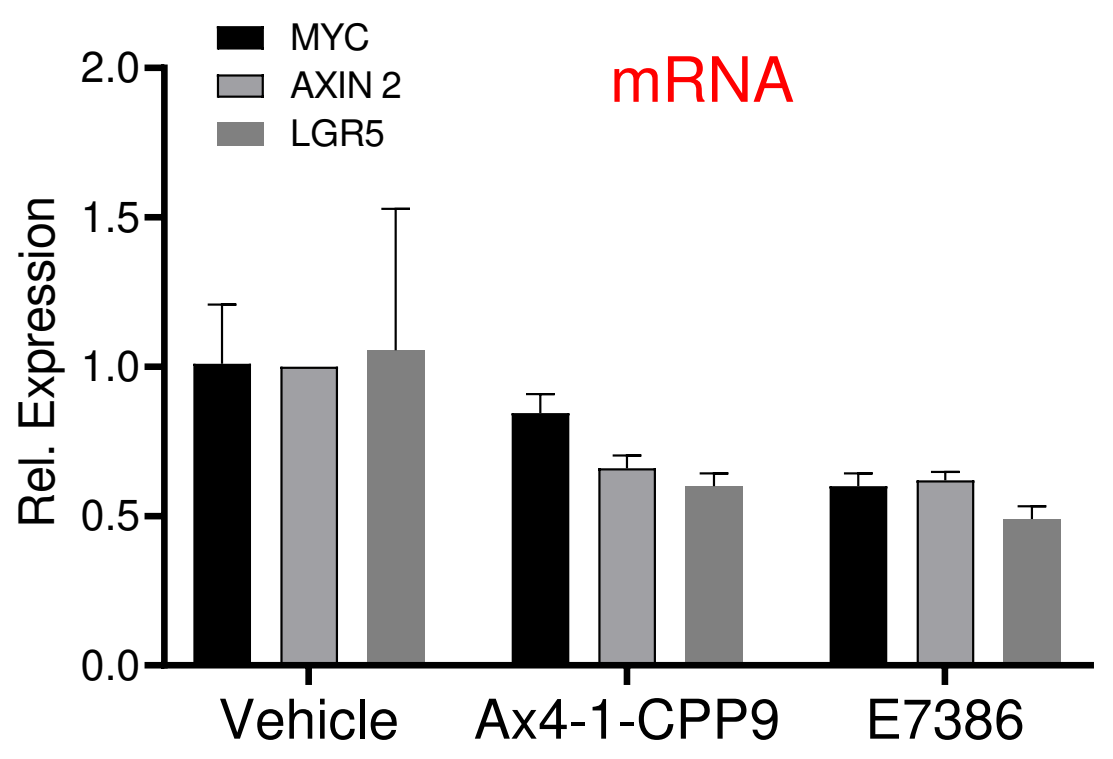

Myc Protein

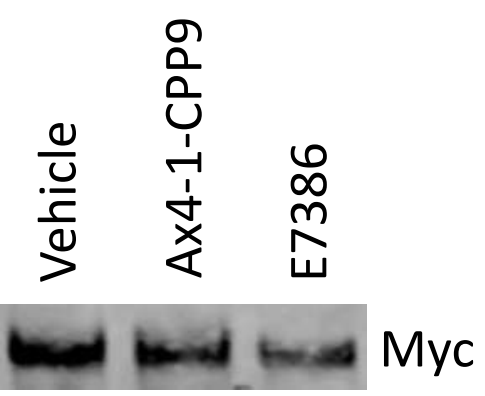

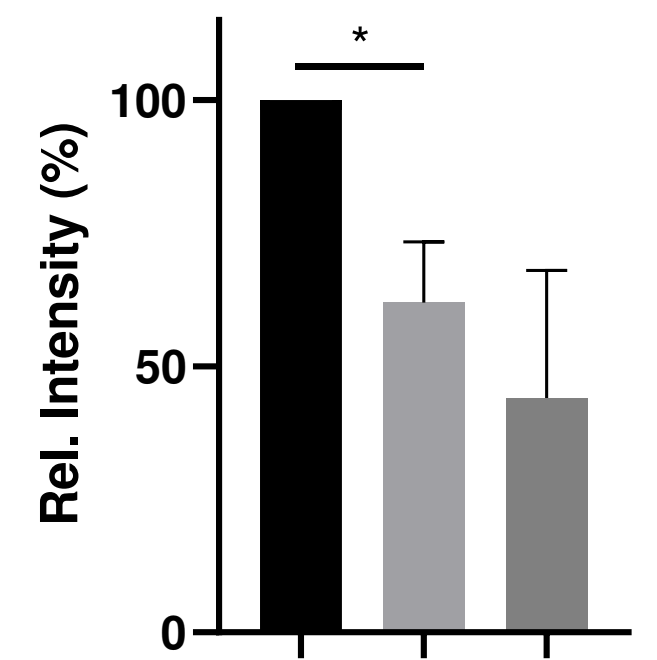

Tubulin

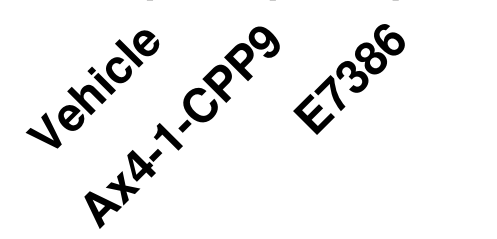




\section{Cytosolic Delivery of Other Stapled Peptides}
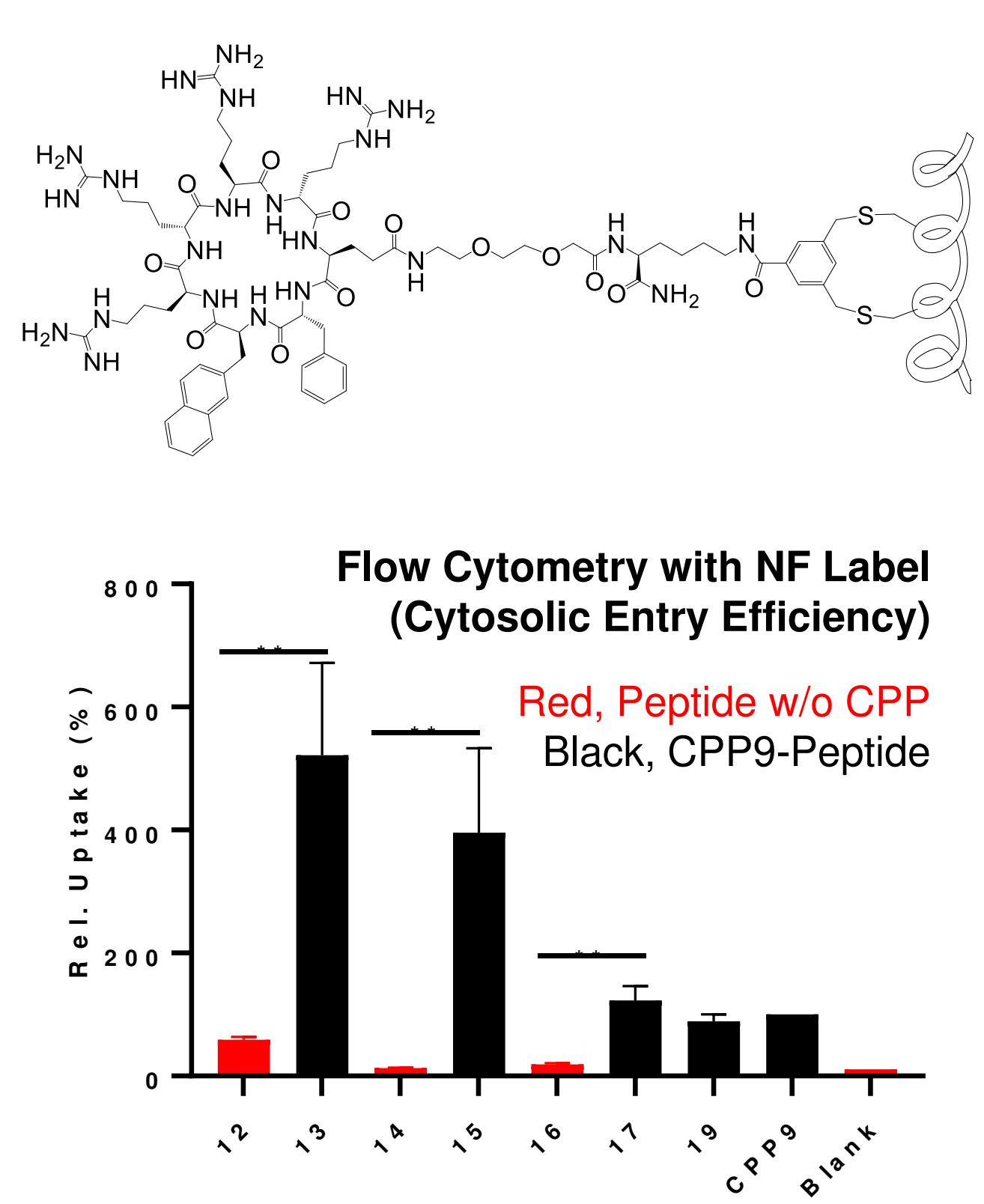
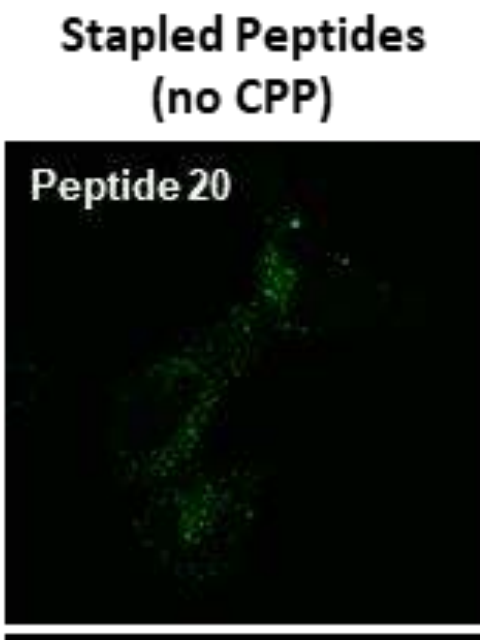

\section{Peptide 22}

CPP9-Peptide Conjugates

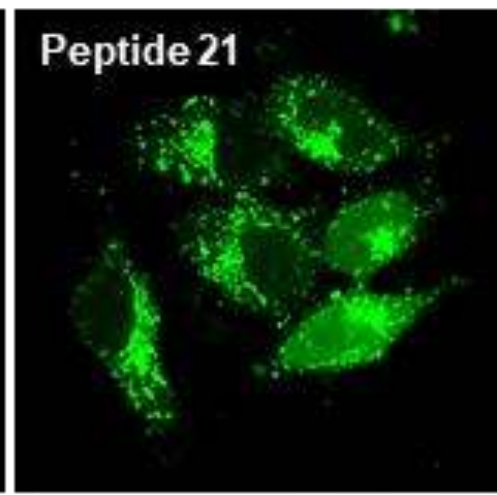

Peptide 23

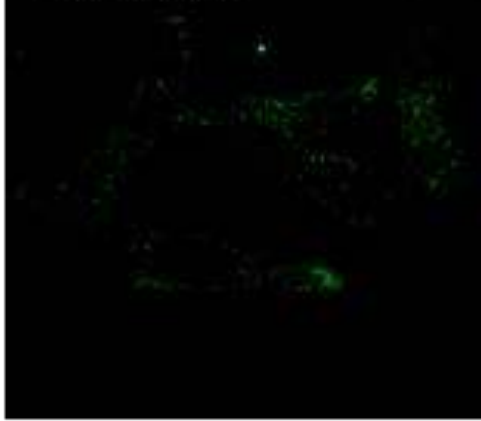

Peptide 24

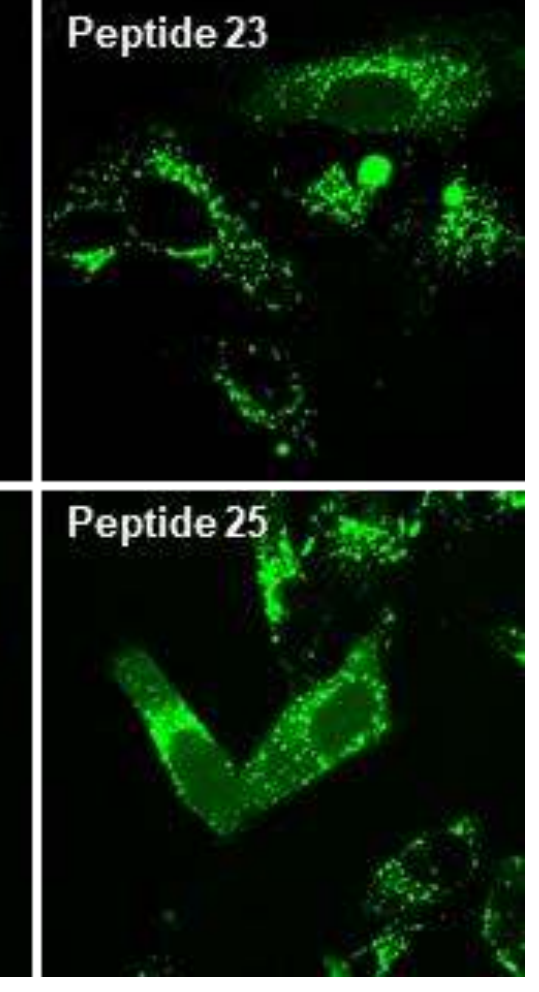




\section{Conclusion:}

- Conjugation to CPP9 increased the cytosolic entry efficiency of stapled peptides by 11 - to 200 -fold;

- Conjugation to a cyclic CPP represents a general method for cytosolic delivery of stapled peptides. 


\section{Cytosolic Delivery of Macrocyclic Peptides: Keap1-Nrf2 Interaction Inhibitor}

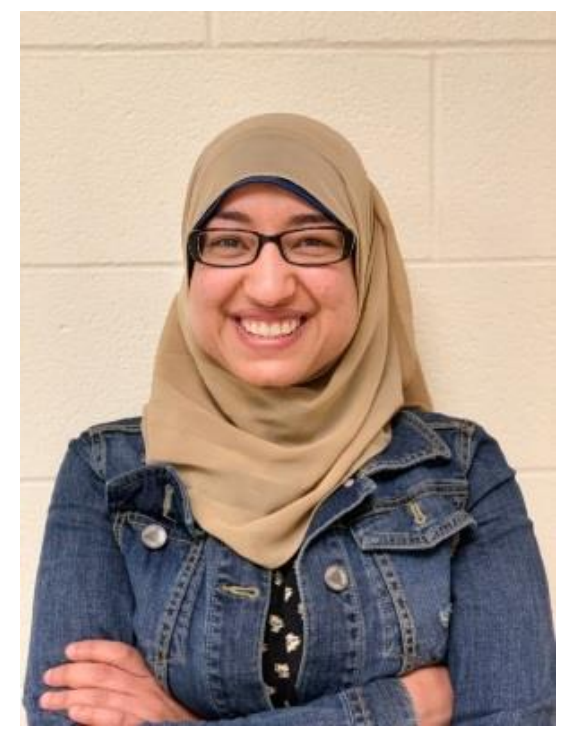

Heba Salim

J. Org. Chem. 2020, 85, 1416. 


\section{Keap1-Nrf2 Interaction and Stress Response}

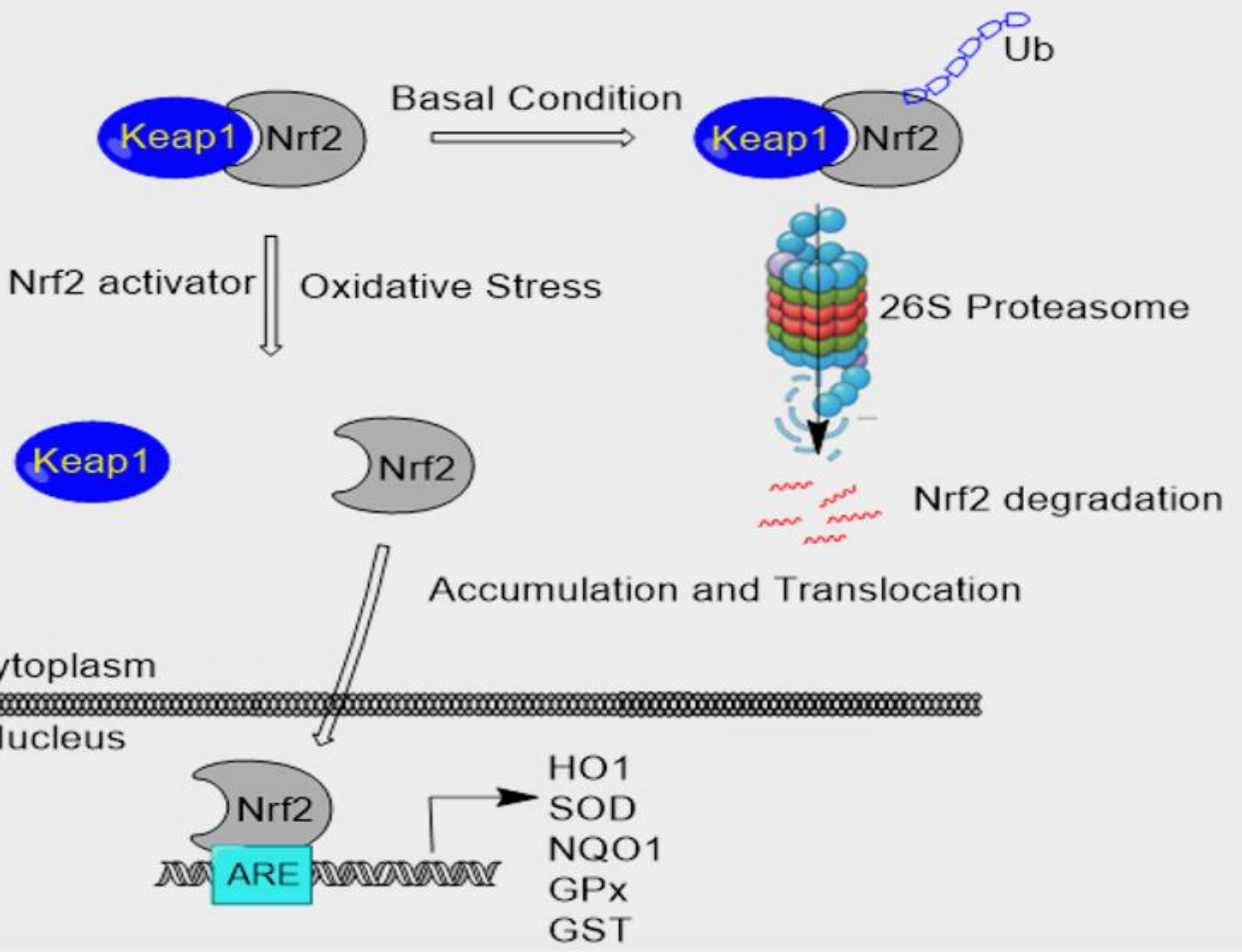




\section{Macrocyclic Peptidyl Keap1-Nrf2 Inhibitor}

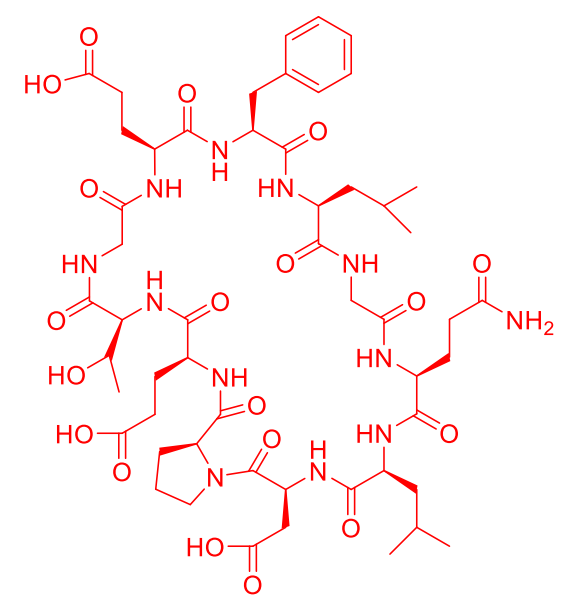

Peptide $1\left(K_{\mathrm{D}}=18 \mathrm{nM}\right)$ Low cell-permeability Lu et al. Eur. J. Med. Chem. 2017

Confocal Microscopy

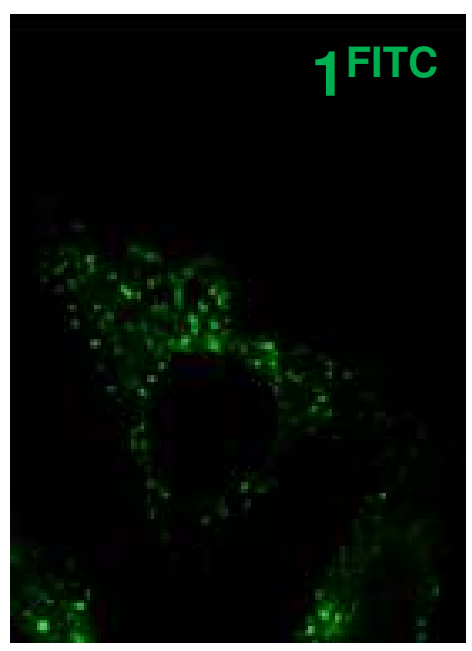

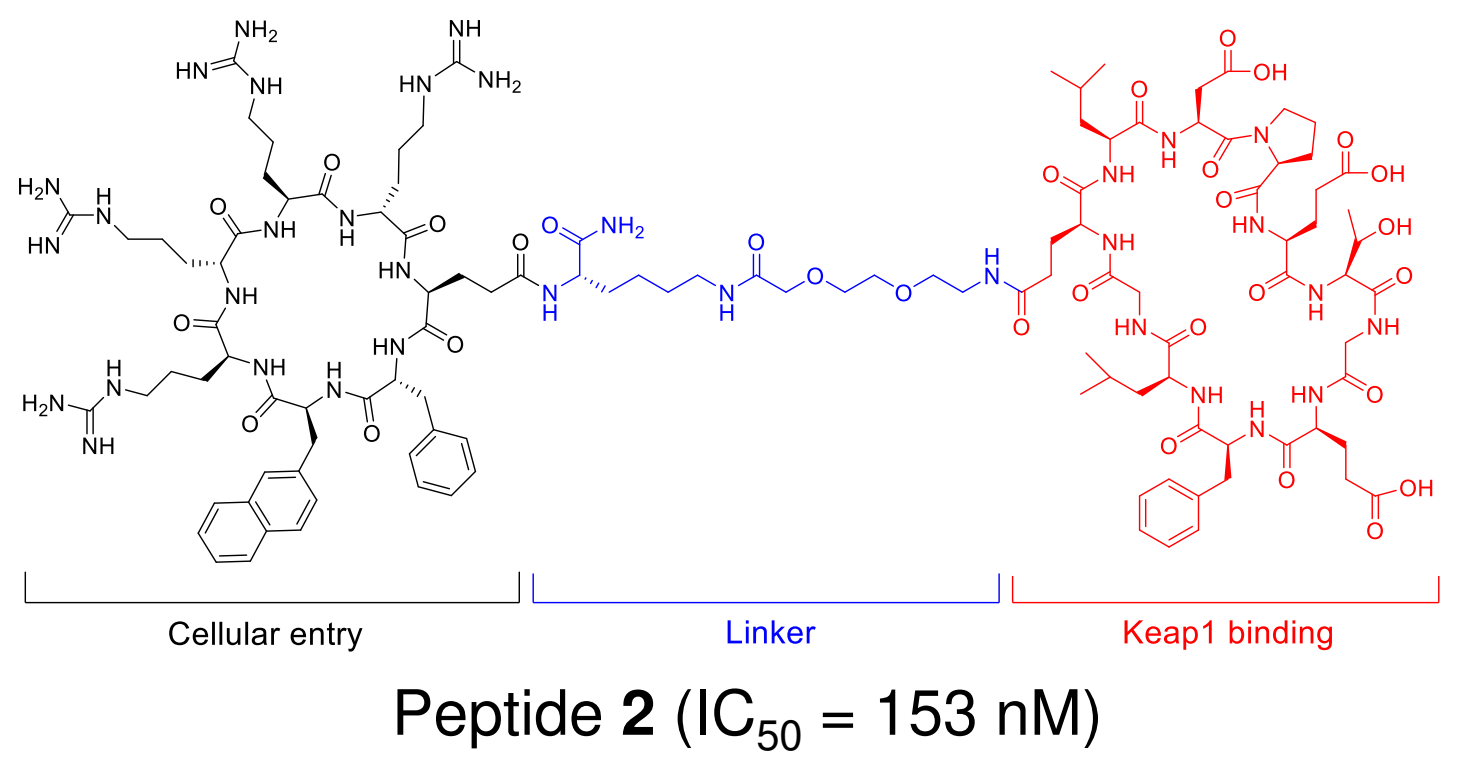

Flow Cytometry (Naphthofluorescein)

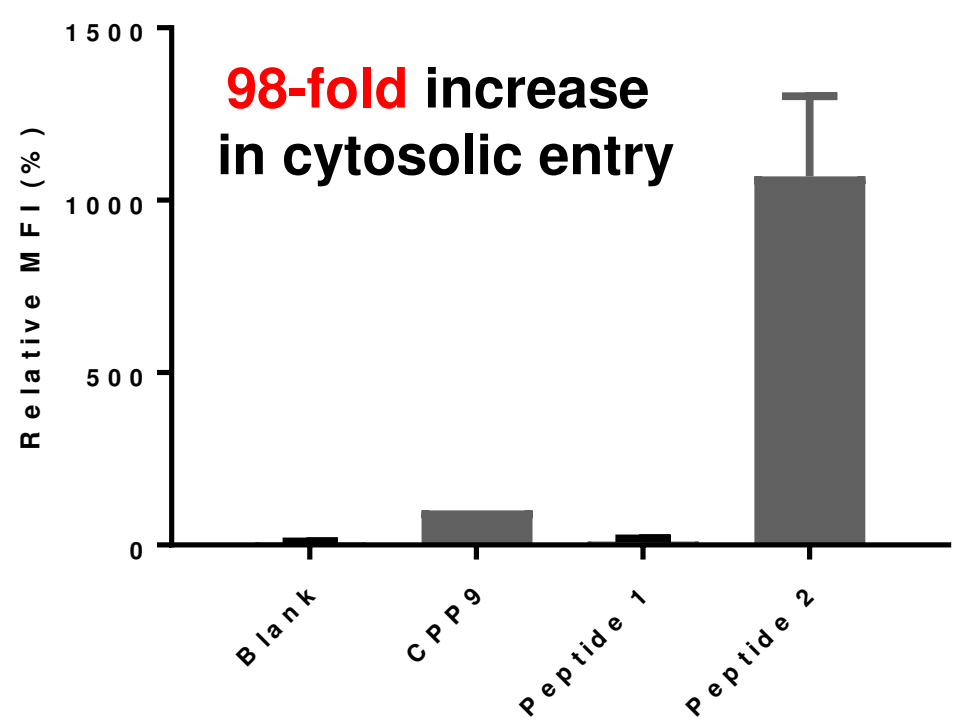




\section{Macrocyclic Peptidyl Keap1-Nrf2 Inhibitor}
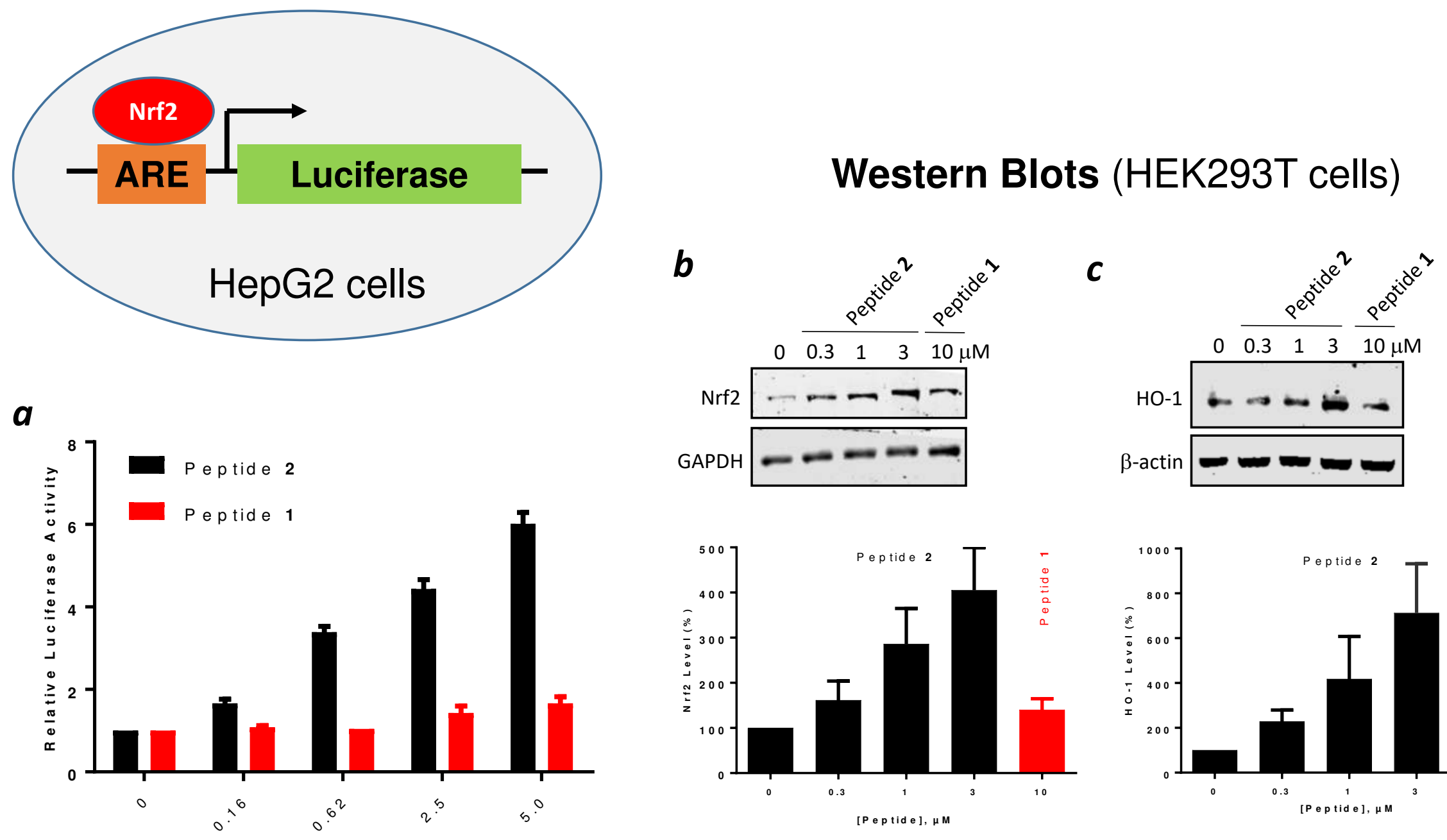

[p e p tid e], $\mu \mathrm{M}$
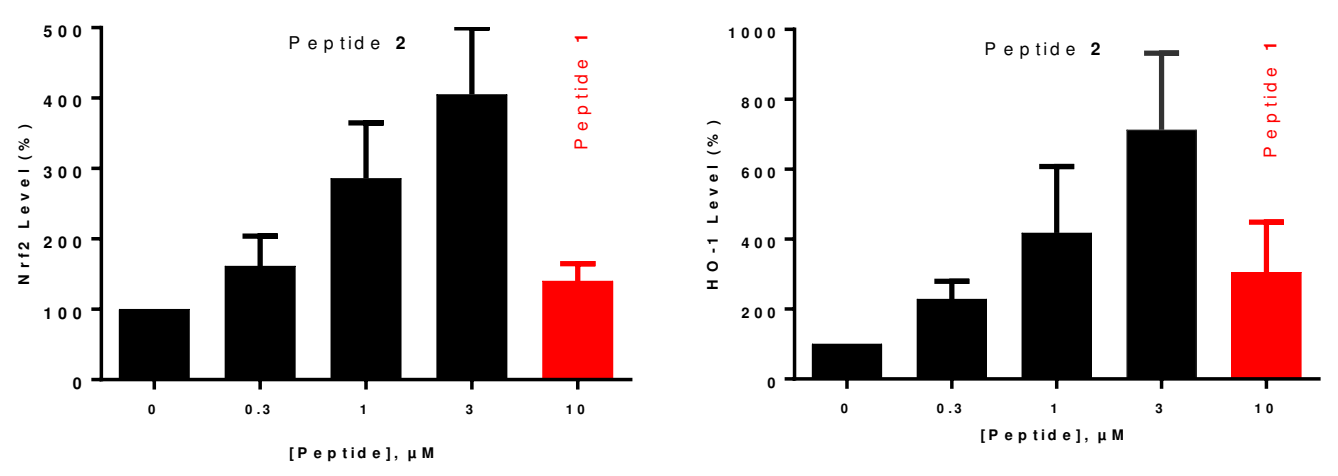

- Peptide 2 dose-dependently increases the transcriptional activity of Nrf2. 


\section{Integration of Cell Penetration and Target Binding: Bicyclic Peptidyl Inhibitors of NEMO-IKK Interaction}

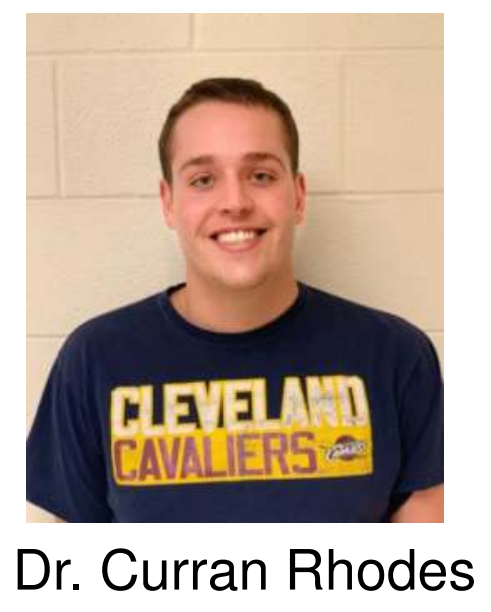

J. Am. Chem. Soc. 2018, 140, 12102. 


\section{NEMO-IKK Inhibitors for Treating Cancer and Inflammation}

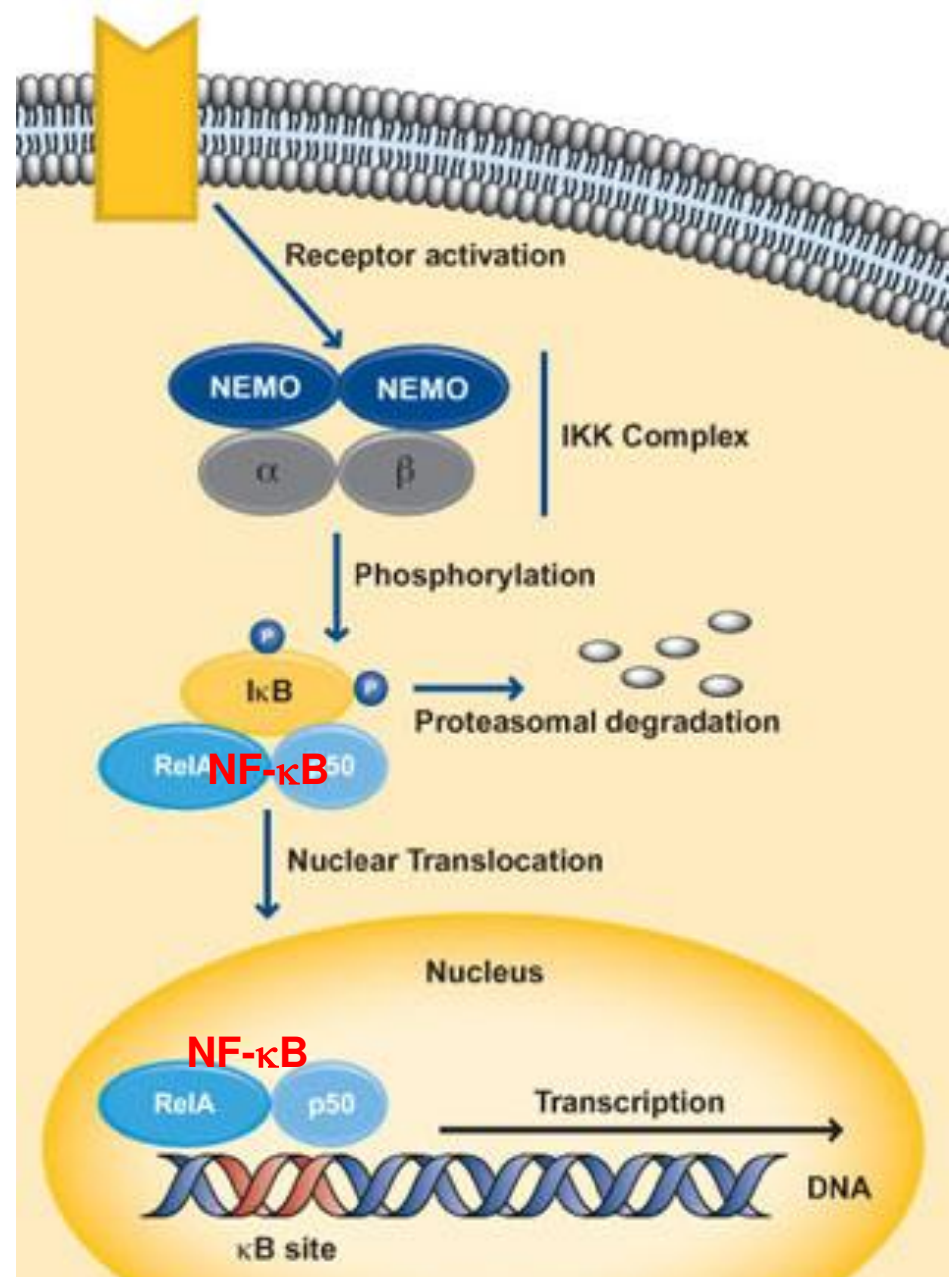

- Excessive NF-kB causes inflammation and cancer resistance to chemotherapy and radiotherapy

- NEMO-IKK interaction activates IKK and NF-KB signaling

- NEMO-IKK inhibitors are expected to be effective for treating inflammatory diseases and cancer

- Antp-NBD is effective for treating Duchenne muscular dystrophy (DMD) and B-cell lymphoma in mice and dogs:

\section{RQIKIWFQNRRMKWKKGGTALDWSWLQTE Antp NBD}

- Problem: Very low potency $\left(K_{\mathrm{D}} \sim 50 \mu \mathrm{M}\right)$ and poor pharmacokinetics (serum $t_{1 / 2} \sim 15 \mathrm{~min}$ ) 


\section{NEMO-IKK $\alpha / \beta$ Inhibitor from a Bicyclic Peptide Library}
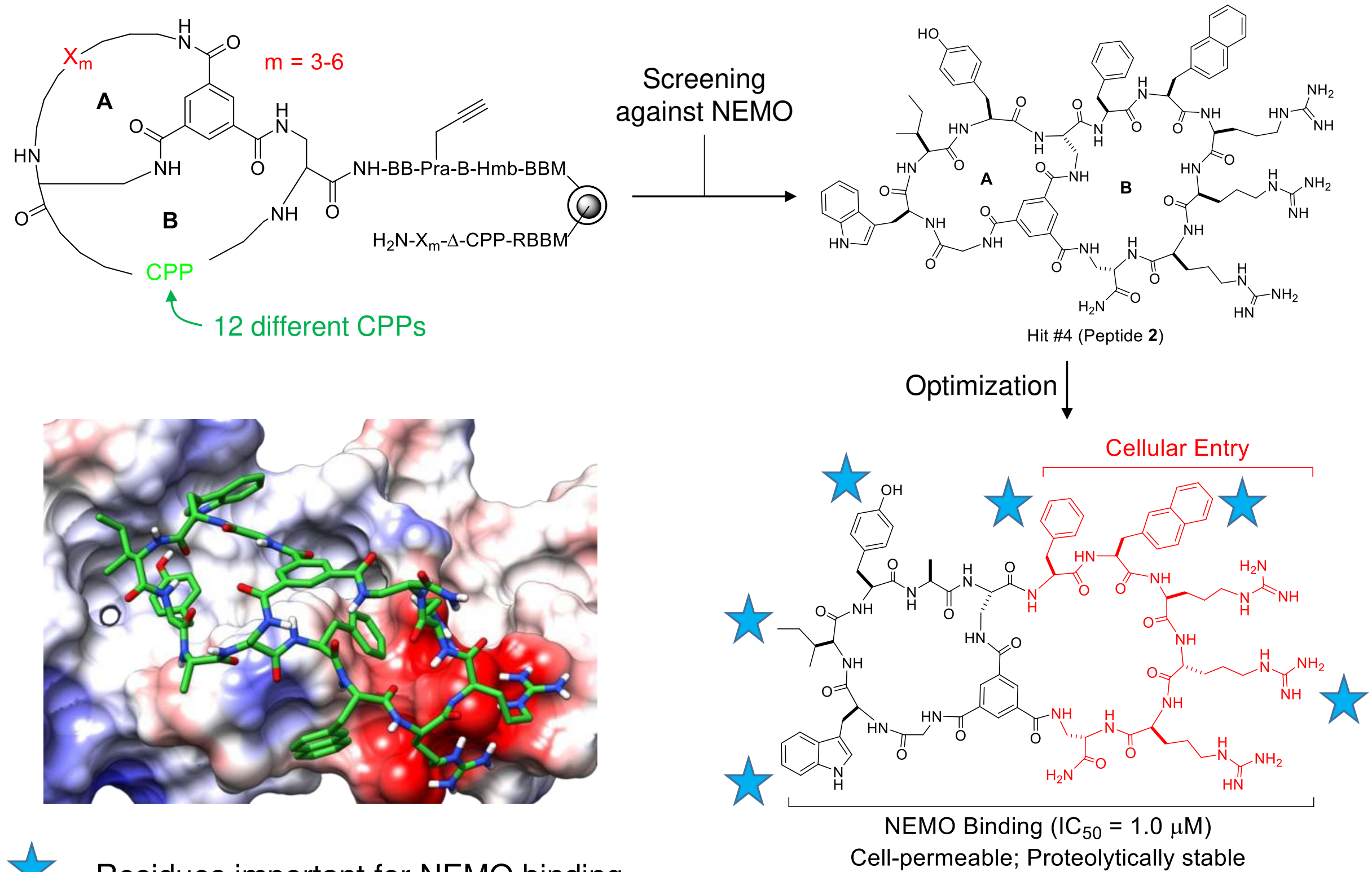

$\hat{W}=$ Residues important for NEMO binding 


\section{Bicyclic Inhibitor against NEMO-IKK $\alpha / \beta$ Interaction}

Canonical NF-кB Signaling Pathway

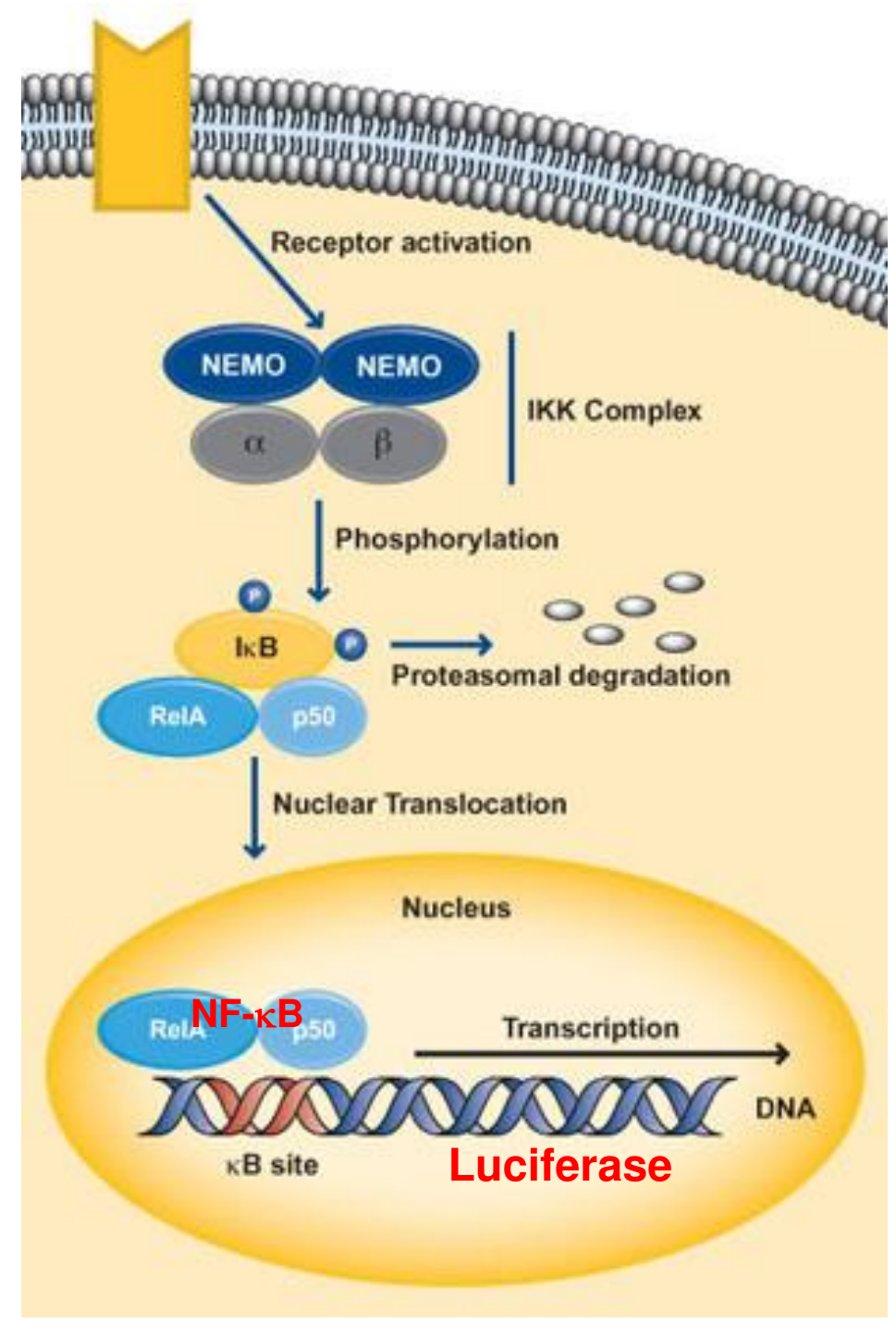

Inhibition of Canonical NF- $\kappa B$ Signaling in HEK293(Luc) cells:

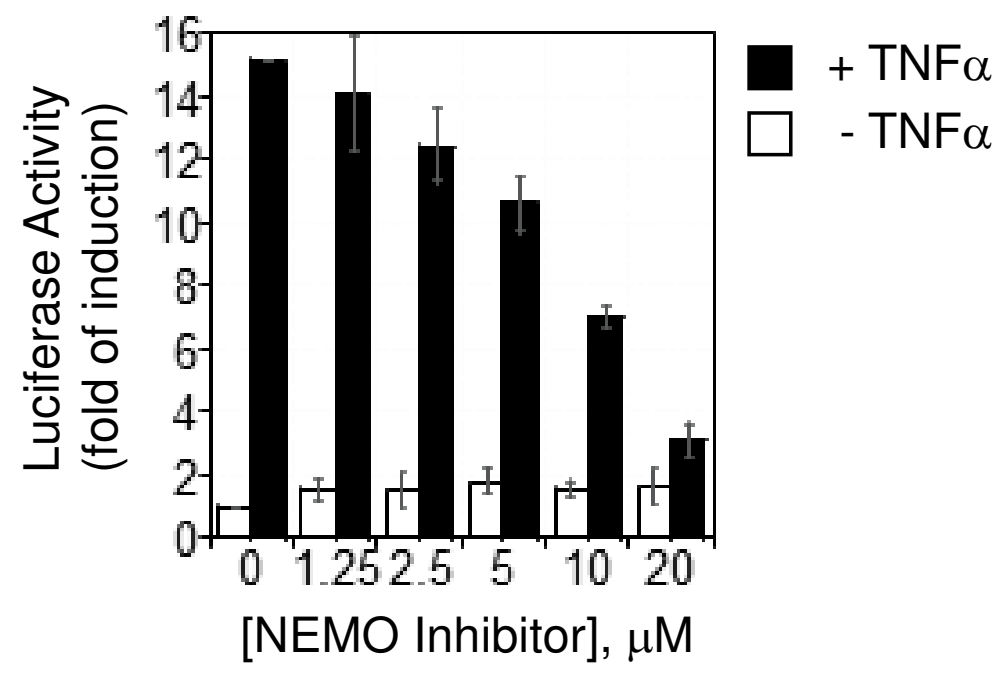

Effect on $\mathrm{p}-\mathrm{IKK} \beta$ and $\mathrm{I} \mathrm{B} \alpha$ Levels in HT29 (human colon adenocarcinoma) Cells:

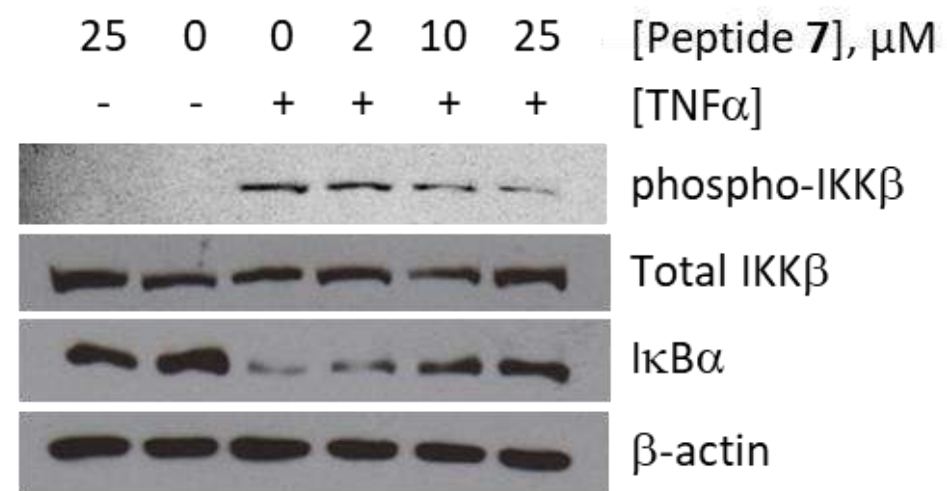




\section{Anti-proliferative Activity of Bicyclic NEMO Inhibitor}

Inhibition of Ovarian Cancer Cells (A2780 and CP70) but not Normal Ovarian Surface Epithelial (OSE) Cells:

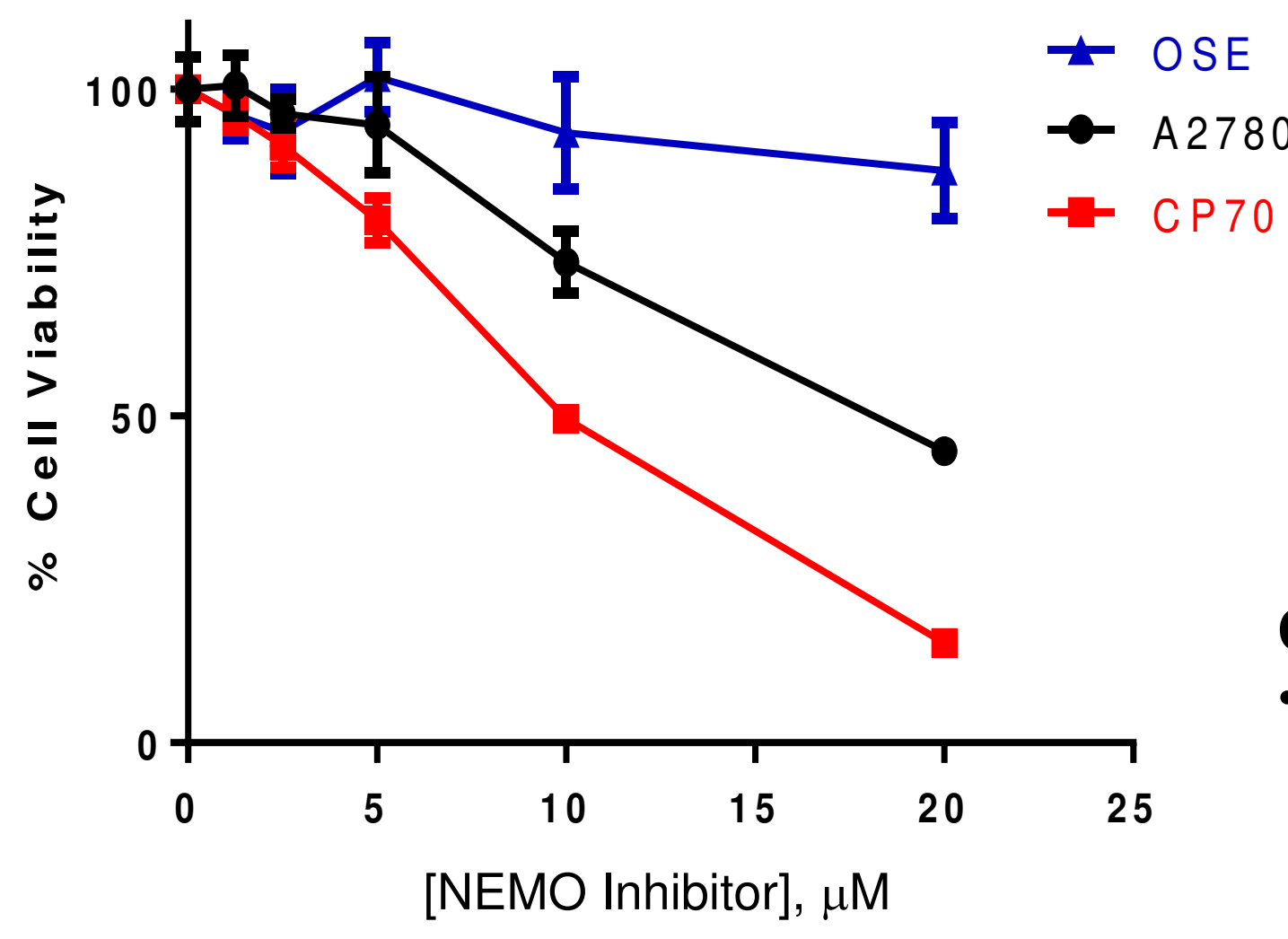

Conclusion:

- Macrocyclic peptides can be designed so that the same residue(s) serves dual function of cell penetration and target engagement. 


\section{Summary}

- Highly active cyclic CPPs provide a general vehicle for cytosolic delivery of biologics (e.g., peptides, proteins, and nucleic acids).

- Potent, cell-permeable, and metabolically stable peptidyl inhibitors can now be designed to specifically target intracellular proteinprotein interactions (e.g., calcineurin-NFAT, $\beta$-catenin-TCF, Keap1-Nrf2, and NEMO-IKK interactions). 


\section{Acknowledgments}

\section{Pei Group Members}

Former:

Dr. Tao Liu

Dr. Sang Hoon Joo

Dr. Punit Upadhyaya

Dr. Wenlong Lian

Dr. Ziqing (Leo) Qian

Dr. Hui Liao

Dr. Jin Wen

Dr. Patrick Dougherty

Dr. Curran Rhodes

Prof. Rui Yang

\section{Current:}

Dr. Kuangyu Chen

Dr. Chao Hong

George Appiah-Kubi

Marina Buyanova

Jordan Hempfling

Ashweta Sahni

Amritendu Koley

Heba Salim

Ruchira Basu

Sarah Pruitt

Amar Sarkar

Prabhat Bhat

\section{Collaborators}

osu

Professor John Christman (OSU Heart \& Lung Institute)

Dr. Manjula Karpurapu

Professor Qi-en Wang (OSU Medical School)

Dr. Sara Cole (OSU Microscopy Core Facility)

Entrada Therapeutics

Dr. Ziqing Qian

Dr. Jian-Guo Ren

Dr. Natarajan Sethuraman

$\$ \$ \$ \$ \$ \$ \$ \$ \$ \$ \$ \$ \$ \$ \$ \$ \$ \$ \$ \$ \$ \$ \$ \$ \$ \$ \$ \$ \$ \$ \$ \$ \$ \$ \$$

NIH (R35 GM122459; R01 CA234124)

Entrada Therapeutics, Inc.

NIH Center for Accelerated Innovations - Cleveland Clinic

Cystic Fibrosis Foundation

The Ohio State University 